\title{
NORMAS DE INTERPRETAÇÃO CONTRATUAL NO BRASIL
}

\author{
RULES OF CONTRACTUAL INTERPRETATION IN BRA7.IL
}

Newton de Lucca ${ }^{\circ}$

\begin{abstract}
Resumo:
Esta matéria analisa o problema das normas de interpretação contratual no País, com ênfase à questão terminológica incluso concepções de contrato existentes na literatura jurídica universal.

Palavras-chave: Normas de interpretação. Contratos. Contratos no Novo Código Civil de 2002.
\end{abstract}

\begin{abstract}
:
This article analyses the problem of the rules of contractual interpretation in Brazil, emphasizing the terminological question including conceptions of contract in the universal legal literature.
\end{abstract}

Keywords: Interpretation rules. Contracts. Contracts in the New Civil Code of 2002.

1. Considerações introdutórias. Conteúdo e limites do presente trabalho: a questão terminológica

O título do presente artigo poderia despertar no leitor, muito provavelmente, a idéia de que seria examinado, ainda que apenas em caráter meramente introdutório, o conceito do próprio contrato, de vez que é sobre esse instituto que incidirá o nosso exame das normas existentes de sua interpretação. E nada mais natural que assim seja. ${ }^{1}$

Como diz o E. professor Ricardo Luis Lorenzetti, hoje ministro da Suprema Corte da Nação Argentina, após lembrar o mal-estar causado pela teoria contratual: "Los manuales suelen comenzar mostrando su perplejidad frente a la diversidad de significados del vocablo, el amplio espectro de situaciones que abarca y la multiplicidad de cuerpos legales que resultan aplicables" ${ }^{2}$

Professor Associado do Departamento de Direito Comercial da Faculdade de Direito da Universidade de São Paulo. Membro da Comissão de Publicação da Revista da Faculdade de Direito da Universidade de São Paulo. Desembargador do Tribunal Regional Federal da $3^{3}$ Região, do Estado de São Paulo. $<$ newtonde@uol.com.br>.

1 "Sem o conceito" - diz-nos Ortega y Gasset - "não sabemos bem onde começa e onde termina uma coisa. O conceito nos dá a forma e o sentido das coisas"

2 Cf. LORENZETTI, Ricardo Luis. Tratado de los Contratos - parte general. Santa Fé, Argentina: RubinzalCulzoni Editores, 2004. p. 7. 
Daí porque, tendo em vista os limites adrede estabelecidos para esta exposição, estaremos nos desviando, deliberadamente, de uma análise prévia - seja sob a perspectiva diacrônica, seja sob a sincrônica ${ }^{3}$ - das várias concepções de contrato existentes na literatura jurídica universal, ${ }^{\dagger}$ para partirmos da singela idéia (porúm sedimentada, desde há muito) de que o instituto é um acordo de duas ou mais partes ${ }^{5}$ com o propósito de regular os seus direitos e obrigações. ${ }^{6}$

Outra investigação de ampla envergadura - da qual, por força da mesma razão já apresentada, passar-se-á in albis - diz respeito ao importantíssimo conceito de interpretação, que desafía a inteligência humana desde os primórdios da Civilização. C'omo devem ser interpretadas as Sagradas Escrituras, cis uma interrogação expectantc que se pôs, efetivamente, desde os primeiros tempos...?

Assim, não-obstante a relevância de investigar-se o próprio conceito de interpretação ${ }^{8}$ e a despeito da famosa lição de Emilio Betti, para quem a palavra

Veja-se, a propósito, a percuciente análise do citado professor Lorenzelti (id. Ibid.), mostrando a perspectiva diacrônica, isto é, descrevendo a signilicação histórica, através dos tempos, do Direito Romano, do Direito Medieval etc. e a perspectiva sincrônica, vale dizer, empreendida de forma simultânea, compreendendo essa mesma significação no mundo anglo-saxônio, oriental, muçulmano. europeu, latino-americano etc.

4 Como se sabe, hả uma concepção do contrato no Dircito Romano; outra na chamada economia liberal; outra, ainda, na economia do Estado du bem-estar social; outra no neoliberalismo e assim por diante.

5 A possibilidade de existirem mais de duas partes no contrato ficou inequivocamente demonstrada por ASCARELLI, Tullio. O Contrato Plurilateral. In: PROBLE.MAS das Sociedades Anónimas e Direito Comparado. 2. ed. São Paulo: Saraiva, 1969. p. 255-312, no desenvolvimento de sua concepção do contrato plurilateral (op. cit., p. 266 e ss.), de que os modclos societários são o mais eloqüente exemplo. Por outro lado, a idéia de que o contrato "faz lei entre as partes" vem desde o Direito Romano e pode ser encontrada em vários Códigos Civis contemporâneos. Exemplificativamente, a alínea primeira do art. I.134 do Código Civil belga dispõe. em livre Iradução: "As convençōes legalmente estabelecidas tomamse leis para os que as celebraram"

" Escusava dizer, assim, que a chamada "teoria analitica do contrato" na qual sảo estudadas não apenas as proposições normativas. em si mesmas consideradas, mas também as funções geradora e transformadora da linguagem normativa, por razões ainda mais evidentes, será deixada inteiramunté de lado.

7 No livro Imitação de ('risto (título original De Imitatione Christi, in Tomás de Kempis, Ed. Martin Claret, 2002, cap.V, 1, p. 18), por exemplo, vamos encontrar a seguinte passagem a respeito: "Nas Santas Escrituras devi-se buscar a verdade e não a eloqüència. Devemos lê-las com o mesmo espirito com que foram escritas. Nelas devemos buscar a utilidade e não a sutileza de linguagem. Devemos ler, com igual boa vontadi, os livros simples e piedosos como os sublimes e profundos. Não te preocupes em saber se aquele que escreve é pessoa de nomeada pela sua enudição; seja apenas o amor à verdade que te leve à leitura. Considera o que diz o livro e não leves em conta quem o escreveu"

8 Diz o lamoso jusfilósofo SICHES. Recaséns. Tratado General de Filosofia del Derecho. 5. ed. México: Editorial Porrua S.A., 1975. p. 627: "El estúdio sobre la interpretación de las normas juridicas no es un tema complementario. Es muchísimo más: es un tema esencial lo mismo en la tcoria que en la práctica del Derecho. Sin interpretación, no hay posibilidad de que exista ningún orden jurídico. Cierto que algunas veces ha habido legisladores que prohibieron la interpretación de las normas que emitian; pero es evidente que tales legisladores o no sabian lo que estaban diciendo - una descomunal estupidez - o querian decir otra cosa, probablemente querían decir que ordenaban una aplicación estricta y severa (lo qual, en fin de cuentas, constituye tambièn una tonteria de gran tamaño)" Não-obstante a extrema profundidade com que esse autor enfrentou o tema da interpretação, a ele consagrando o último capítulo (21) dessa sua obra, o mesmo foi ainda mais desenvolvido no livro SICHES. Recaséns. Nueva Filosofia de la Interpretación del 
interpretar merece a mais cuidadosa análise, pois ela se presta a uso muitas vezes defeituoso (é utilizada na linguagem corrente em vários sentidos, capazes de gerar confusões conceituais), apenas de passagem aludiremos a tão tormentosa questão. E. independentemente do vasto campo de indagações que tal matéria suscita. também aqui ficaremos com a síntese do grande autor italiano, segundo a qual o processo interpretativo responde ao problema epistemológico de entender. ${ }^{9}$

Isto não significa, é claro, que o nosso trabalho esteja simplesmente reduzido a entender o que dizem os artigos de lei relativos à interpretação dos contratos. Em Direito, por certo, isto não nos basta, e toda a obra de Betti nô-lo demonstra... ${ }^{10}$

Em grosseiro resumo de autor tão profundo poderíamos alinhavar, apenas. umas pálidas idéias. Citando alguns exemplos, o grande Autor peninsular mostra que, designar como interpretação. "uma explicação subjetiva do mundo proposta por um pensador, filósofo ou poetu," constituiria uma impropriedade. Aludir-se à "interpretação da vontade" como recorrentemente se faz. apresenta caráter ambiguo. Na atividade cognoscitiva da interpretação, como se disse, reside o problema epistemológico de entender.

Utilizando-se de uma distinção corriqueira ao jurista entre "ação" e "evento", Betti caracteriza a interpretação como sendo "a ação cujo evento útil é entender:" E prossegue esclarecendo que se cuida de uma atividade que exige a espontaneidade espiritual de quem é chamado a entender, sendo que tal exigência não pode ser cfetivamente cumprida sem sua ativa colaboração. Trata-se, assim, de um processo cognoscitivo peculiar no qual atua, de um lado. o espírito vivente e pensante daquele que interpreta $e$, de outro, uma espiritualidade objetivada em forma representativa. Tais lados se conjugam, segundo a mediação daquela forma representativa, na qual a espiritualidade objetivada vem encontrar-se com o sujeito que interpreta como algo independente dele, com objetividade tal que poderia ser qualificada

Derecho. México: Dianoia Fondo de Cultura Fconômica, 1956.

- Cf. BETTI, Emilio. Teoria Generale della Interpretazione. Milāo: Giuffrè. 1955, especialmente as p. 1-57 (Prolegomeni a una Teoria Generale della Interpretazione) c p. 59-289 (Capitulo I, Il prublema epistemologico dell 'intendere quale aspetto del problema generale del conoscere). Ainda sobre o mesmo tema da interpretação. veja-se, Interpretazione della legge e degli atti giuridici. Milão: Giuffrè. 1971, na qual nos baseamos, fundamentalmente, para as considerações, a seguir expendidas, no sexto principal.

ii Veja-se, exemplificativamente, essa sugestiva passagem (Id. Ibid., p. 92): "Qui, interpretare non è soltanto tornare a conoscere uma manifestazione di pensiero. ma tornare a conoscerla. per integrarla e realizzarla nella vita di relazione. L'interpretazione, qui, non ha uma funzione meramente ricognitiva del pensiero (di un pensiero in sè conchiuso nella sua storica peculiarità), ma la funzione di sviluppame direttive per l'azione pratica o per un'opzione; e cosi assolve il compito di mantenere semprc in vita. mediante l'intendere, lê esigenze di um ordine dell'operare, e precipuamente assolve il compito di conservare in perenne eflicienza nella vita di una società norme. precelti c valutazioni normative. che sono destinate a regolarla o a servirle di orientamento". 
de irremovivel. Conhecer, como fenômeno de interpretação, é reconhecer, é reconstruir o espirito que, mediante a forma de sua objetivação, fala ao espírito daquele que interpreta. Algo diferente, portanto, do "conhecer" de um fenômeno que ocorre no mundo fisico.

Espera-se do intérprete uma objetividade de tal ordem que a sua reprodução daquilo que foi objeto da representação seja o mais fiel possível ao valor expressivo ou sintomático, mas essa exigência de objetividade só se perfaz pela própria subjetividade de quem interpreta. Há uma verdadeira antinomia, segundo o Autor italiano: de um lado, a subjetividade, inseparável da espontaneidade de entender; de outro, a objetividade, por assim dizer, a autenticidade do sentido que se trata de encontrar. Poder-se-ia dizer, grosso modo, que Betti desenvolve a construção da sua teoria geral da interpretação, a partir dessa antinomia na qual está baseada toda a dialética do processo interpretativo." A teoria da interpretação, para ele, não pode ser exclusivamente jurídica, embora ela tenha no Direito uma aplicação especial. Daí a sua formulação de uma teoria geral de interpretação válida para todas as ciências culturais, mencionando os mais variados tipos de interpretação e ordenando-os de conformidade com suas funções respectivas.

A primeira função existente em todo processo interpretativo é, para ele, a meramente cognoscitiva ou recognoscitiva. A segunda é a função reprodutiva ou representativa. Nesta o processo de entender é um "meio" para atingir um "fim" ulterior, qual seja. o de fazer entender a um grupo de destinatários. Trata-se de uma interpretação subjetiva e pessoal, já que aquele que interpreta entende e transmite aos outros uma obra tal qual ele a concebe. A terceira função é chamada de função normativa, na qual também o entender serve a um fim ulterior, no caso, o de fornecer "la massima della decizione" ou. em geral, da ação com o propósito de assumir determinada posição na vida social. $^{12}$

Abstemo-nos de reproduzir a percuciente e acurada análise - por extrapolar os lindes da presente investigação -, empreendida pelo grande Autor italiano, a propósito da interpretação histórica e normativa do Direito, na qual ele examina, em profundidade. a interpretação da Ciência Jurídica, cotejando a interpretação histórica com a interpretação normativa ou diretiva da conduta feita pelo jurista.

1 Dai porque, para o Autor, trata-se sempre de entender a objetivação de uma espiritualidade, sendo uma impropriedade da linguagem aludir-se à interpretação dos chamados fenômenos naturais.

12 A partir dessas três funçōes, Betti classifica as várias formas de interpretação da seguinte maneira: 1. formas de interpretação em função meramente recognitiva: a) interpretação filológica; b) interpretação histórica; 2. formas de interpretação em função reprodutiva ou representativa: a) tradução; b) interpretação dramática; c) interpretação musical: 3 . formas de interpretação em função normativa: a) interpretação juridica: b) interpretação teológica; interpretação psicológica. 
Apenas para finalizar, cumpre pôr em realce a importantíssima função do intérprete, para Emílio Betti. Ela não se esgota quando ele simplesmente empreende a reconstrução da idéia originária da fórmula legislativa - o que, efetivamente, não está dispensado de fazê-la -, mas deve necessariamente adaptá-la à realidade presente, infundindo a vida desta, transfundindo a norma em elemento da vida social presente a cujo serviço a norma se encontra. ${ }^{13}$

Ficam assim -.. apenas palidamente entrevistas - as principais idéias de Emílio Betti a respeito da teoria geral da interpretação. Façamos, agora, breve alusão ao pensamento de alguns autores que se ocuparam do tema.

"Interpretar uma expressão de Direito" - ensinou nosso grande jurista Carlos Maximiliano, ${ }^{14}$ calcado em Enneccerus ${ }^{15}$ - "não é simplesmente tornar claro o respectivo dizer, abstratamente falando; é, sobretudo, revelar o sentido apropriado para a vida real, e conducente a uma decisão reta", acrescentando, logo a seguir que: "Não sc trata de uma arte para simples deleite intelectual, para o gozo das pesquisas e o passatempo de analisar, comparar e explicar os textos; assume, antes, as proporções de uma disciplina eminentemente prática, útil na atividade diária, auxiliar e guia dos realizadores esclarecidos, preocupados em promover o progresso, dentro da ordem; bem como dos que ventilam nos pretórios os casos controvertidos, e dos que decidem litígios e restabelecem o Direito postergado."

Despicienda será por certo, igualmente, a tarefa de pôr em realce a importância da interpretação contratual. Sabe-se que, no acordo de vontades estabelecido entre as partes, pode haver inteira simetria entre o que desejaram, por ocasião da avença, e a posterior expectativa dos direitos e obrigações por elas assumidas. Em tal hipótese, não há necessidade da interpretação propriamente dita. O sentido e o alcance das cláusulas contratuais coincidem plenamente, quer no processo interno de formação do acordo de vontades, quer no processo ulterior de exteriorização dessas vontades.

Quando, porem, inexistir tal simetria, frustrando as expectativas das partes quanto ao sentido e o alcance das cláusulas contratuais, torna-se absolutamente decisivo o processo da interpretação contratual a fim de que sejam afastadas as dúvidas, omissões, obscuridades ou contradições existentes naquelas cláusulas.

13 Diz essc Autor em outra passagem bastante expressiva (Op. cit., p. 93): "In codesta funzione genericamente normativa cui è destinata, nell'ufficio cioè di formire la massima della decisione e dell'azione, l'attività interpretativa presuppone e contiene in sć tantu il momento meramente ricognitivo. quanto anche un momento riproduttivo o rappresentativo. Invero l'interprete ha bisogno anche qui di ricostruire. anzitutto. lidea originaria della formola legislativa, o il senso iniziale dell'atto giuridico, pur non avendo, con questo, finito di adempiere ii suo compito"

If Cf. MAXIMILIANO. Carlos. Herménêutica e Aplicação do Direito. 19. ed. Rio de Janeiro: Editora Forense, 2004. p. 8.

is Cf. ENNECCERUS. Ludwig. Lehrbuch des Bürgerlichen Rechts. 8. ed. 1921. v.1. \$48. 
Köhler, um dos principais representantes do chamado método históricoevolutivo, ao combater o verbalismo exegético ensinou que:

Interpretar é escolher, dentre as muitas significações que a palavra possa oferecer, a justa e a convenicnte. Por isso mesmo, a lei admite mais de uma interpretação no decurso do tempo. Supor que há somente uma interpretação exata, desde que a lei é publicada até os seus últimos instantes, é desconhecer o fim da lei, que não é objeto de conhecimento, mas um instrumento para se alcançar os fins humanos, para fomentar a cultura. conter os elementos antisociais e desenvolver as energias da nação. ${ }^{16}$

A atividade do intérprete do contrato não pode ser inteiramente livre, pois existem comandos legais que indicam um caminho a ser percorrido por ele, seja na interpretação da própria lei, seja na do contrato. É certo que o grande jusfilósofo Luis Recaséns Siches, em obras de maior envergadura sobre a doutrina hermenêutica. explicou que "a função jurisdicional e o modo de exercê-la escapam a qualquer criação legislativa, não pertencem a ela, não podem ser colocados dentro dela. Em consequiência, quando o legislador quer dizer aos juizes de que modo estes haverão de interpretar a lei, suas palavras nesta matéria resultarão necessariamente inoperantes (grifos do Autor)" concluindo que "o legislador pode incluir em seus mandatos legais tudo quanto considerar oportuno: mas a função jurisdicional é uma coisa diferente, e só pode ser da competência do órgão que a exercer autorizadamente" 17 De outro lado, é igualmente certo que, sem que a atividade jurisdicional fique comprometida por causa de determinados comandos legais, o magistrado deverá obedecer a certos balizamentos em sua atividade de intérprete, quer da lei, quer do contrato.

Lapidar, a propósito, a disposição do art. $5^{\circ}$ do Decreto-Lei n. 4.657 , de 4 de setembro de 1942 (texto epigrafado como Lei de Introdução ao Código Civil

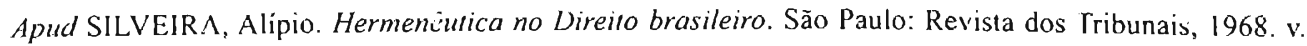
II, p. 67.

Apud SII.VEIRA. Alípio. cit.. p. 77. 
Brasileiro $)_{3}^{18}$ segundo a qual: "Na aplicação da lei, o juiz atenderá aos fins sociais a que cla se dirige e às exigências do bem comum"

Referindo-se a uma "identidade fundamental" existente entre a "lógica do razoável”, de Recaséns Siches, e o conteúdo desse art. $5^{\circ}$, diz-nos com inteira propriedade o jurista Alipio Silveira:

A técnica hermenêutica do 'razoável', ou do 'logos do humano' é a que realmente se ajusta à natureza da interpretação e da adatação da norma ao caso. A dimensão da vida humana, dentro da qual se contém o Direito, assim o reclama. O fetichismo da norma abstrata aniquila a realidade da vida. A lógica tradicional. de tipo matemático ou silogístico, não serve ao jurista, nem para compreender e interpretar de modo justo os dispositivos legais, nem para adatá-los às circunstâncias dos casos concretos. O juiz realiza, na grande maioria dos casos, um trabalho de adatação da lei ao caso concreto, segundo critérios valorativos alheios aos moldes silogisticos.

Tal disposição do art. $5^{\circ}$ da nossa Lei de Introdução. longe de cercear a atividade jurisdicional, permite ao magistrado escapar do positivismo jurídico exacerbado com o qual, ao longo da História, tanto se exerceu, sem maiores dificuldades, a odiosa e injusta dominação dos mais fracos pelos mais fortes...

Mesmo não sendo este o momento adequado, é claro, para a exposição do que entendemos por positivismo jurídico, parece-nos necessário a fim de que as nossas ulteriores considerações não fiquem prejudicadas em seu real significado --, abrir um

18 Tivemos a oportunidade de assinalar, recentemente, em prefácio escrito à obra de MARQUES, Cláudia Lima. Confiança no comércio eletrônico e a proteção do consumidor - negócios juridicos de consumo no comércio eletrônico. São Paulo: Revista dos Tribunais, 2004. p. 14-15, a impropriedade de tal epigrafe nos seguintes termos: "Esse texto. como se sabe, não-obstante a sua designação, na verdade não disciplina questões de Direito Privado e sim de Direito Público tal é a natureza inquestionável dos seus artigos iniciais ou, igualmente, de Direito Internacional Privado... Trata-se de uma lex legum, de um sobredireilo, que não se vincula ao Direito Civil, mas a todos os outros ramos do Direito" Os professores e magistrados GAGLIANO. Pablo Stolze; PAMPLONA FILHO, Rodolfo. Novo Curso de Direiro Civil. São Paulo: Saraiva, 2002. v. I, p. 59, esclarecem que: "Mais técnico seria. inclusive, se fosse denominada 'Lei de Introdução às Leis', sendo efctivamente uma regra de superdireito. aplicável a todos os ramos do ordenamento jurídico brasileiro, seja público ou privado" A prof. Maria Helena Diniz já houvera assinalado, com precisão (DINIZ. Maria Helena. Lei de Introdução ao Código Civil Interpretada. 7. ed. São Paulo: Saraiva, 2001. p. 4), que "Como se vê, engloba não só o Dircito Civil, mas também os diversos ramos do Direito Privado e Público, notadamente a seara do Direito Internacional Privado. A Lei de Introdução é o Estatuto de Direito Internacional Privado; é uma norma cogente brasileira, por determinação legislativa da sobcrania nacional, aplicável a todas as leis" Utiliza-se, igualmente, como vimos, a expressão superdireito, devida, segundo consta, a Zitelmann. Diz-nos, a propósito, TRINDADE, Washington Luiz da. O Superdireito nas Relações de Trabalho. Salvador: Editora e Distribuidora de Livros Salvador Lida., 1982. p. 15: "O termo deve-se a E. Zitelmann e tem sido assimilado a Direito Hermenêutico. como regra áurea de aplicação e de interpretação de textos legais ou de relações materiais de Dircito comum. mancjada pelos órgãos realizadores do Dircito“. 
pequeno parêntese ${ }^{19}$ a fim de que seja devidamente explicado em que sentido estamos e estaremos empregando a palavra positivismo no presente trabalho. ${ }^{20}$

A expressão "positivismo" - cunhada, pela vez primeira, por Augusto Comte, em seu Cours de la philosophie positive, publicado entre 1830 e 1842 apresenta caráter evidentemente polissêmico, conforme oportunamente salientado por Genaro Carrió nos seguintes termos:21

A expressão positivismo jurídico é intoleravelmente ambigua. Foi utilizada e tem sido usada ainda para designar uma variedade heterogênea de atitudes, teses, concepções e doutrinas, todas as quais se relacionam, de distintas maneiras, com o fenômeno social denominado "Direito" Algumas delas são incompativeis entre si. Outras estão ligadas por laços familiares. Por tudo isso, para identificarse a linha geral das idéias de determinado jurista não basta, na maioria dos casos, em dizer que se trata de um positivista. Ademais, quando alguém dirige os seus ataques, de forma indiscriminada, contra o 'positivismo jurídico' o que ele estiver querendo dizer poderá tornar-se muito confuso se não esclarecido em qual dos sentidos está sendo utilizada dita expressão.

Bobbio identificara, num dos mais luminosos estudos a respeito da matéria, ${ }^{22}$ três significados distintos para a expressão "positivismo jurídico": um primeiro, como enfoque metódico; um segundo, como ideologia; e, por último, um terceiro, com o sentido de uma teoria. Para afastar-se, então, o perigo a que se referiu Carrió, seja-nos permitido esclarecer que a alusão ao positivismo jurídico, linhas atrás, foi feita no segundo sentido destacado por Bobbio, vale dizer, empregada a expressão como uma espécie de ideologia, consistente numa atitude valorativa diante do Direito Positivo, segundo a qual, em sua vertente extremada e mais encontradiça no meio judiciário brasileiro, existiria uma obrigação moral de obedecer, de forma

19 Por mais estranha que possa parecer a presente nota, principalmente em uma obra destinada à leitura de não-brasileiros, fico perplexo ao pensar o que deve supor um estrangeiro - que. eventualmente, esteja se esforçando por entender a língua portuguesa - ao ler em autores de nomeada, no Brasil, a alusão de que será aberto "um parêntesis", como sc não existisse a expressão "parêntese", no singular... Abre-se "um parêntesc" e, como ele deve ser posteriormente fechado, o que escrevemos ficou entre "parênteses" Mesmo a expressão "dois parêntesis" revela-se inadequada, segundo o gramático Napuleão Mendes de Almeida, pois devemos adaptar a expressão grega à nossa língua: dois parênteses e não dois parênıesis. Mas este último equivoco até que seria desculpável sc, pelo menos, fossem dois parîntesis e não apenas um...

- Tentaremos sintetizar, neste passo, as considerações que já desenvolvemos em nosso DE LUCCA. Newton. Direito do Consumidor - -. Teoria Geral da Relação Juridica de Consumo. São Paulo: Editora Quartier Latin, 2003.

21 Cf. ('ARRIÓ, Genaro. Notas sobre Derecho y lenguage. 4. ed. Buenos Aires: Abeledo-Pcrrot, 1990. p. 321 .

22 BOBBIO. Norberto. Sul positivismo giuridico. Rivista di Filosofia, v. LII, n. 14, 1961. 
axiologicamente cega, aos ditames das leis e dos regulamentos existentes, independentemente das conseqüências que possam advir de sua indiscriminada aplicação...

Voltemos, agora, ao árduo tema da interpretação. A despeito de uma famosa e irônica passagem de Montaigne, ${ }^{23}$ para quem "dispendemos mais esforços interpretando as interpretações do que interpretando a realic'ade, e escrevemos mais livros sobre livros do que sobre qualquer outro assunto" parecendo concluir, com grande desapontamento, que "o que fazemos é, tão-só, nos entreglosar", a presente investigação propõe-se, exatamente, a tentar interpretar o que dizem as normas dos principais diplomas legais brasileiros a respeito da tarefa da interpretação.

Adepto que sou do estudo do Direito comparado. penso que a presente obra coletiva prestará inestimável serviço aos estudiosos do [ireito. Ninguém põe em dúvida a enorme importância desse estudo, desde os tempos da Antigüidade, ${ }^{24}$ quando já se considerava absolutamente indispensável para o legislador o conhecimento dos direitos de outros paises.

23 MONTAIGNE, Michel de. Essais. Paris: Gallimard, Livro III, cap. XIII.

24 Ao tratar do surgimento da Ciência Juridica comparativa no mundo, Marc Ancel (Utilidade e Métodos do Direito Comparado, tradução do Prof. Sérgio José Porto, Sergio Antonis Fabris Editor, Porto Alegre, 1980) dá notícia de suas "origens longinquas". destacando que Licurgo, eın Esparta, e Sólon. em Atenas, teriam viajado pelo mundo conhecido daquela época para conhecer as instituições antes de se porem a legislar, u mesmo acontecendo com os decênviros que, antes de cumprirem o encargo de elaborar a Lei das XII Tábuas, cuidaram de se informar sobre as leis estrangeiras, particularmente as gregas. que também haviam influenciado a primeira legislação escrita em Roma. Consta, também, que Platão se utilizou de comparações em As Leis, enquanto Aristóteles discutiu as constituições existentes em sua época (Cf. Politica, 1266 30, sobre a ('onstituição de Fáleas; idem. 1267b, 20. solıre a de Hipodamo de Mileto; idem, 127lb, 20, com o exame crítico da Constituição de Creta e, em 127? b, a Constituição de Cartago). Alude-se, ainda, ao ensaio de justaposição de duas legislações do mundo antigo, no século $\mathrm{V}$ depois de Cristo, denominado "Collatio legum Romanarum el Mosaicarum», para apenas ficarmos nos exemplos relativos à Antigüidade. Muito tempo depois - mas muito antes ainda de falar-se em Direito comparado -, Montesquieu serviu-se, em seu famoso Espril des Lois, do método de comparação de instituições politicas de diferentes povos, podendo ser mencionada a sua reflexão sobre as leis em suas relações com os diversos seres, no Livro Primeiro, e sobre as leis que derivam diretamente da natureza do governo. constante do Livro Segundo. ALMEIDA. Carlos Ferreira de. Introdução ao Direito Comparado. 2. ed. Coimbra: Almedina, 1998. p. 13, professor da Faculdade de Direito da L'niversidade de Lisboa, afirma que "a mais impressionante premonição do futuro Direito comparado pertence a I.eibniz que, em obra publicada em 1607, formulava o projecto de um theatrum legale mundi descritivo dos direitos de todos os povos, em todos os tempos e lugares" Esclarece esse mesmo autor que a instituciunalização do Direito comparado deu-se na segunda metade do século XIX, com o surgimento das primeiras associaçòes cientificas e revistas de Direito comparado, com primazia cronológica para a Société de Législanon Comparée, fundada em Paris no ano de 1869, data cm que tem início a publicação de seu Boletim mensal. Nesse mesmo ano. tem inicio o ensino do Direito comparado na Universidade de ()xford, sendo que, já em 1851. houvera tal disciplina sido implantada na Universidade de Madri. Em 1890 deu-se sua criação cm Paris. 
2. Normas de interpretação no novo Código Civil (Lei n. 10.406, de 10 de janeiro de 2002)

No que se refere às normas de interpretação, em seu sentido estrito, ${ }^{25}$ poder-se-ia dizer, num primeiro exame perfunctório de algumas de suas disposições, não ter havido alterações significativas trazidas pelo novo Código Civil em relação ao Código anterior, de 1916. Como veremos, a par da repetição literal de um artigo, outras disposições foram mantidas quase inalteradas, com ligeiros acréscimos feitos. Tal não significa, contudo, que algumas novas contribuições importantes não tenham sido oportunamente acrescentadas, conforme será visto mais adiante.

Antes de passarmos, contudo, à necessária comparação entre os dois diplomas civis brasileiros incluindo-se em tal cotejo, igualmente, os artigos do Código Comercial, de 1850. que ficaram revogados pela unificação da matéria obrigacional promovida pelo novo Código -, parecem oportunas algumas breves considerações sobre essa unificação.

Sobre a extinção da dualidade do Direito Privado brasileiro, a maioria da doutrina nacional - desde Teixeira de Freitas, em 1858, com a Consolidação das leis civis clamava pela unificação obrigacional, pois não havia, propriamente falando, uma duplicidade de sistemas.

Expressivas, a propósito, as palavras do Eminente professor Fábio Konder Comparato:" "Temos, pois, que não há, propriamente, contraposição de dois sistemas jurídicos distintos, em matéria de obrigações: o do Código Civil e o do Código Comercial. O que há é um só sistema, no qual os dispositivos do Código do Comércio aparecem como modificações específicas das regras gerais da legislação civil, relativamente às obrigações e contratos mercantis. A duplicidade legislativa aparece, tão-só, no que tange a essas regras de exceção, dentro do sistema global"

Estamos nos utilizando da expressão "normas de interpretação em sentido estrito" com o propósito de diferenciá-la de "normas de interpretação em sentido amplo" Enquanto, na primeira, vamos encontrar comandos ditados pelo legislador ao magistrado, no ato de interpretar os contratos, na segunda o que existe são diretrizes gerais ditadas por normas de caráter principiológico, assim entendidas aquelas que orientam não apenas o magistrado, em seu ato de julgar, como as próprias partes, na conduta que estas devem assumir durante toda a vigência do contrato. Tome-se, como exemplo, o principio da boa-fé verdadeiramente um metaprincípio do nosso sistema juridico atual - absolutamente fundamental no plano do Código de Defesa do Consumidor de 1990. como também agora, no Código Civil de 2002. Conforme scrá visto mais adiante, no texto principal, não se trata de uma norma de interpretação em sentido estrito, mas sim de um princípio geral que deve orientar tanto o juiz. na solução do caso concreto, quanto as partes contratantes, no que se refere à conduta de lealdade por elas assumida.

$\therefore$ Cf. COMPARATO. Fábio Konder. Novos Ensaios ¿ Pareceres de Direito Empresarial. Rio de Janeiro:Forense, 1978. p. 251. 
Dois artigos do velho Código Comercial de 1850 pareciam corroborar, com efeito, a afirmação do citado professor: o art. 121 do Código Comercial, de um lado, segundo o qual "As regras e disposições do Direito civil para os contratos em geral são aplicáveis aos contratos comerciais" e o art. 428 desse mesmo diploma que, por sua vez, dispunha: "As obrigações comerciais dissolvem-se por todos os meios que o Direito civil admite para a extinção e dissolução das obrigações em geral, com as modificações deste Código"

De nossa parte, sempre sustentamos que a unificação das obrigações civis e comerciais deveria ser promovida pelo novo Código, à míngua de uma diferença ontológica entre elas que justificasse a duplicidade legislativa. De outro lado. porém, vivemos defendendo a idéia de que a realidade empresarial, por força de sua própria dinâmica, deveria ser objeto de um microssistema à parte e não objeto de um livro dentro do próprio Código Civil. ${ }^{27}$

Passemos, então, à comparação a que se aludiu nas linhas inaugurais do presente capitulo entre os dois códigos civis brasileiros. O primeiro confronto a ser feito é o do art. 85 do CC, de 1916, com o art. 112 do CC, de 2002.

O artigo 85 do CC, de 1916. assim dispunha:

Nas declaraçôes de vontade se atenderá muis à sua intenção que ao sentido literal da linguagem.

O NCC, ${ }^{28}$ de 2002 estabelece, em seu art. 112, in verhis:

Nas declarações de vontade se atenderá mais à intenção nelas consubstanciadu do que ao sentido literal da linguagem.

27 Veja-se, a propósito, nosso artigo intitulado DE LUCCA, Newton. A atividade empresarial no àmbito do Projeto de Código Civil. In: SIMÃO FILHO, Adalberto; DE LUCCA, Newton (Coords.) Direito Empresarial Contemporâneo. 2. ed. São Paulo: Juarez de Oliveira, 2004. p. 31-88. Sobre essa noção de microssistema são numerosos os trabalhos existentes. Cf., entre outros, GOMES, Orlando. A caminho dos microssistemas: novos temas de Direito Civil. Rio de Janeiro: Forense, 1983. p. 40 e ss. Ver, igualmente, NERY JÚNIOR, Nelson. Código Brasileiro de Defesa do Consumidor comentado pelos autores do anteprojeto. 4. ed. Rio de Janciro: Forense Universitária, 1995. p. 285 e ss. e TEPEDINO, Gustavo. $O$ Código Civil. os chamados microssistemas e a Constituição: premissas para uma reforma legislativa. In: PROBLEMAS de Direito Civil. Rio de Janeiro/ São Paulo: Editora Renovar, 2000. p. 1-16. Para uma visão histórica e sistêmica desse fenômeno denominado "piccolo mondo di norme", no dizer de Natalino Irti. fundamentais as leituras tanto da obra clássica desse autor sobre o tema (IRTI. Natalino. L'elá della codificazione. 4. ed. Milão: Giuffrè, 2000. p. 46), como do estudo de VARELA, João de Matos Antunes. $O$ movimenıo da descodificaçào do Direito Civil. In: ESTUDOS juridicos em homenagum ao Professor Caio Mário da Silva Pereira. Rio de Janeiro: Editora Forense. 1984) no qual esse autor descreve a trajetória ora caracterizada pelo fastigio, ora pélo declinio - do movimento codificador.

28 Sigla que passará a ser utilizada, doravante, com o propósito de simplificação do texto, para designar o novo (ódigo Civil brasileiro. 
Ambas as disposições, sem dúvida, têm sua origem no velho brocardo latino, a Celso atribuido, segundo o qual "scire leges, hoc non est verba earum tenere, sed vim uc potestatem" ou, numa livre tradução de nossa parte, "saber as leis não é reter as suas palavras, mas a sua força e o seu poder"

Poder-se-ia dizer, numa primeira aproximação, que a alteração promovida é meramente redacional. Tem-se a impressão de que a expressão "nelas consubstanciada" no novo Código, teria apenas o significado de aprimoramento de estilo do legislador. Numa segunda aproximação, no entanto, é possível perceber que há, efetivamente, um sentido maior na modificação promovida. É que não havia, no art. 85 do Código, de 1916, uma referência à vontade que deveria ser exteriorizada e interpretada, embora tal omissão jamais tenha causado algum problema no entendimento desse art. 85.

Diz-nos a respeito o E. prof. Arruda Alvim:29

Demonstrar-se-á que o art. 85 do Código Civil de 1916 que não continha essas expressões ${ }^{30}$ - jamais foi entendido em sua literalidade, e que a redação atribuída ao vigente artigo 112 do Código Civil veio expressar adequada e corretamente a relação necessária entre vontade (contcúdo) e declaração (continentc), no plano dos negócios jurídicos e dos contratos, no sentido de que, se uma dada vontade não foi declarada, não é possível tomá-la em consideração. No caso do que se disse, não é possivel conhecer-se o conteúdo, se não existe o continente. (grifos do autor)

Mostrando que a redação do vigente art. 112 coadunou-se, inteiramente, com o entendimento dominante na doutrina civilistica pátria, no que concerne à teoria dos negócios jurídicos e à dos contratos, prossegue esse mesmo professor:

O que veio a significar a redação do atual art. 112 do Código Civil, em relação àquela que estava no art. 85 , com a inserção, neste último texto. das expressões "nelas consubstanciada", foi que passou a ser o texto vigente expressão de pensamento que guarda sintonia com a doutrina contemporânea; c mesmo em relação à vigência do artigo 85 do Código Civil de 1916, era esse o pensamento, pois a literalidade do texto jamais autorizou que a sua interpretação se circunscrevesse ao seu âmbito literal. (grifos do autor)

29 Cf. ALVIM, José Manuel Amuda. A sintonia da redação do art. 112 do Código Civil com os principios contemporâneos do negócios juridico bilateral e do contrato. Revista do Advogado, São Paulo, v. 24, n. 77. p. 13-|6, jul. 2004.

30 Refere-se o autor à expressão "nelas consubstanciada" 
De toda sorte, tirante esse aspecto específico já assinalado - e que, de resto, não interfere no cerne da presente exposição - o fato é que o espirito do dispositivo continua sendo rigorosamente o mesmo, isto é, a interpretação gramatical não deverá prevalecer sobre a verdadeira intenção das partes. As explicações de Clóvis Beviláqua, a respeito do revogado art. 85 do $\mathrm{CC} / 16$, permanecem atuais:

$A$ vontade manifesta-se por sinais ou simbolos, entre os quais ocupam lugar proeminente as palavras. Esses sinais ou palavras podem não traduzir, fielmente, o que o agente quer exprimir: A lei, por isso, manda atender, de preferência, à intenção, desde que haja elementos para determiná-la, fora da expressão verbal imperfeita, indecisa, obscura ou insuficiente. ${ }^{31}$

E nos remata o grande civilista pátrio:

Este preceito é mais do que uma regra de interpretação. $\dot{E}$ um elemento complementar do conceito do ato jurídico. Afirma que a partc essencial ou nuclear do ato jurídico é a vontade. É a ela, quando manifestada de acordo com a lei, que o Direito dá eficácia. ${ }^{32}$

Sílvio de Salvo Venosa, no mesmo sentido, preconiza:

Nessa pesquisa, o intérprete examinará o sentido gramatical das palavras e frases, os elementos econômicos e sociais que cercaram a elaboração do contrato, bem como o nível intelectual e educacional dos participantes, seu estado de espírito no momento da declaração etc. ${ }^{33}$

A segunda comparação a ser feita diz respeito ao art. 1.090 do $C C$, de 1916, e o art. 114 do NCC, de 2002. Pelo revogado art. 1.090, "os contratos benéficos interpretar-se-ão estritamente" Já o atual art. 114 estabelece que "Os negócios jurídicos benéficos e a renúncia interpretam-se estritamente" Sobre tais disposições, diz-nos Álvaro Villaça Azevedo: ${ }^{34}$

Por sua vez., o art. 114 do novo Código Civil (art. 1.090 do Código (ivil antigo) acolhe o princípio de hermenêutica, segundo o qual devem ser interpretados, estritamente, os contratos benéficos, pois que, contendo estes uma liberalidade, não pode esta aumentar-se por obra de interpretação, o que viria a conferir maiores vantagens do

3 Cf. BEviláQua, Clóvis. Código Civil dos Estados Unidos do Brasil comentado. 11. ed. Rio de Janciro: Francisco Alves, 1956. v. I. p. 265.

32 Id. Ibid., p. 266.

33 Cf. VENOSA, Silvio de Salvo. Teoria geral dos contratos. 2. ed. São Paulo: Allas, 1996. p. 80.

34 Cf. AZEVEDO. Álvaro Villaça. Teoria geral dos contrutos tipicos e atipicos: curso de Direito Civil. São Paulo: Ed. Atlas, 2002. p. 55. 
que as pretendidas pelo beneficiador. O mesmo acontece com a necessária interpretação estrita da renúncia, que ressalta do primeiro dispositivo legal citado. Também, o mesmo princípio instala-se no art. 819 do novo Código Civil (art. 1.483 do Código anterior), que reconhece a impossibilidade de a fiança, que deve, sempre, provar-se por escrito, ser interpretada extensivamente: tudo porque é a fiança uma garantia pessoal que presta o fiador ao afiançado, em contrato de que participa este, como devedor. Assim, a fiança é verdadeiro favor, que não pode ser ampliado por interpretação, que venha a aumentar os ônus de scu contcúdo.

O alcance da alteração promovida, no presente caso. é evidentemente muito maior. Em primeiro lugar, porque o NCC, adotando a teoria alemã do negócio jurídico, ${ }^{35}$ precisou que não seriam os contratus benéficos que seriam interpretados estritamente, mas sim os negócios juridicos, conceito mais amplo, evidentemente. do que aquele existente para o contrato. ${ }^{36}$ Em segundo lugar, porque o artigo incluiu a renúncia como outra espécie de negócio jurídico a ser interpretado de forma estrita.

Quanto ao sentido dessa primeira alteração - a adoção da teoria do negócio juridico como modalidade específica dos atos juridicos - cabem algumas observações adicionais.

Inegável terá sido a evolução ocorrida no que se refere ao acolhimento da teuria alemã do negócio jurídico. O Eminente ministro Moreira Alves. autor da Parte Geral do Anteprojeto. cuidou de fazer a pertinente e sábia distinção entre os negócios jurídicus e us atos jurídicos. Estes últimos haviam sido conceituados, no Código Civil. de 1916, como todos aqueles que, contando com o pressuposto da licitude, tenham por

35 Sobre a teoria geral do negócio jurídico, na qual são estudados os elementos qui o compòem, quais sejam. os essenciais (essentialia negotii), os naturais (naturalia negotii) e os acidentais (accidentalia negotii), segundo designação já clássica em sede doutrinária, veja-se a percuciente classificação do AZEVEDO, Antonio Junqueira de. Negócio juridico: existência, validade e eficácia. 193 p. Tese (Livre-docência) Faculdade de Direito, Universidade de São Paulo, p. 41), para quem haveria: "'a) elementos gerais, isto é, comuns a todos os negócios: b) elementos categoriais, isto é, próprios de cada tipo de negócio: c) elementos particulares, isto é. aqueles que existem em um negócio determinado, sem serem comuns a todos os negócios ou a certos lipos de negócio" Nessa mesma obra, também pode ser encontrada, entre outras, interessante investigação sobre o que vem a ser considerado elemento integrante de algo, chamando a atenção para o caráter abstrato de tal análise, e definindo, com precisão, esse mesmo conceito: "Elemento do negócio juridico é tudu aquilo que compòe sua existência no campo do Direito"

36 A sinonimia poderia ser estabelecida entre contratos e negócios jurídicos bilaterais e não simplesmente entre os primeiros e os negócios juridicus genericamente considerados. FLUME, Werner. El negocio juridico. parle general del Derecho Civil. Tradução espanhola. Madricl: Ed. Fundación Cultural del Notariado. 1998. tomo II. cap. VIII, $\S 33,1$, p. 705 , concorda com Savigny no sentido de que as normas dos negócios juridicos são aplicáveis aos contratos, podendo ser considerados estes últimos quase equivalentes em geral aos negócios juridicos entre vivos. 
fim imediato adquirir, resguardar ${ }^{37}$ transmitir, modificar ou extinguir direitos ${ }^{38}$ Também $^{2}$ eles produzem, sem sombra de dúvida, determinados efcitos jurídicos, mas isso não significa possam eles ser considerados negócios jurídicos. Eles não exigem vontade negocial para a sua formação e só apresentam os efeitos que estão na lei especificamente previstos.

O NCC reconhece, destarte, diferentes categorias para o ato juridico, ${ }^{39}$ distinguindo as declarações de vontude de natureza negociul das que, mesmo consistindo em verdadeiras declarações de vontade, não podem ser consideradas como tendo natureza negocial. A estas últimas. o Direito as chama de declarações de vontade de natureza não negocial. ${ }^{40}$

A terceira comparação refere-se ao antigo art. 1.483 do $\mathrm{CC} / 16$, segundo o qual: "A fiançu dar-se-á por escrito, e não admite interpretação extensiva" A redação do atual art. 819 é absolutamente idêntica: "A fiança dur-se-á por escrito, e não admite interpretução extensiva."

Essas comparações que acabamos de fazer entre os arts. $85,1.090$ e 1.483 do CC, de 1916. e os arts. 112,114 e 819 do CC, de 2002. respectivamente, poderiam sugerir, à primeira vista, que as modificações trazidas por este último teriam sido de pequena monta. Não foi, porém, o que ocorreu. O exame cuidadoso de outros dispositivos do novo Código Civil levam. necessariamente. se não à conclusão oposta. pelo menos a uma diversa daquela primeira. Refiro-me aos arts. 113 e 423 - que dizem respeito, especificamente, a normas de interpretação contratual -, e aus arts. 156, 157. 421 e 422, os quais, conquanto não sejam normas de tal nature za. contemplaram as figuras do estado de perigo, da lesão enorme, ${ }^{41}$ da função social do contrato e dos

37 A omissão à conservação dos direitos, como esclarece BI:VILÁQUA, Clóvis. Código Civil dos Estados l!nidos do Brasil Comentado. 11. ed. Rio de Janciro: Francisco Alves, 1956. v. I, p. 261-262, estaria superada pela possivel abrangência de seu conceito no verbo resguardar...

38 Tal era a dicção do art. 81 do nosso Código Civil de 1916, jả revogado: "Todo ato licito, que tenha por fim imediato adquirir, resguardar, transferir: modificar ou extinguir direitos. se denomina ato juridico"

39 Os atos juridicos lícitos foram previstos no art. 185 do NCC, aplicando-se-lhes, no que couber, as disposições do Título relativo aos negócios jurídicos quando, com estes, não se confundircm.

to MIRANDA, Francisco Cavalcanti Pontes de. Tratado de Direito Privado: pane geral. 4. ed. São Paulo: Revista dos Tribunais, 1983. 1. 3, p. 4 e ss., insistia na distinção entre declarações de vontale e manifestações de vontade, asseverando que: "Com o emprego altemado, ou desatento, das expressōes 'declarações de vontade' e 'manifestações de vontade'. os juristas levaram o cunceito de negócio juridico a imprecisões lamentáveis. Desse modo, o primeiro cuidado que se há de ter. em exposição cientifica. é o dc se responder à questão básica: ¿Existem negócios juridicos em que o suporte fático seja manifestação simples, em vez de declaração de vontade? A resposta é afirmativa. ainda se não se dilata. como. erradamente, fazem alguns, o conceito de declaração de vontade. atí conter o de manifestações nãodeclaradas de vontade; e negativa, se não se mantém a distinção, já assente no Direito comum, entre declarações de vontade, atuações (manifistações simples, adeclarativas) de vontade e atos reais, e se tomam a esses e aos outros atos-fatos como se fossem manifestações de vontade". (grifo do autor). 
princípios de probidade e de boa-fé, respectivamente, institutos que já vinham sendo de há muito reivindicados, de certa forma, pela doutrina civilista dominante.

Examinemos, então, mais estes seis artigos, começando pelos dois concernentes a normas de interpretação contratual, qual sejam, os arts. 113 e 423 .

Diz o primeiro deles:

Os negócios juridicos devem ser interprelados conforme a boa-fé e os usos do lugar de sua celebração.

A doutrina brasileira, de maneira geral, saudou com entusiasmo este dispositivo, a ele se referindo como a consagração da chamada boa-fé objetiva, já anteriormente albergada pelo Código de Defesa do Consumidor $^{42}$ e, antes deste, na verdade, pelo Código Comercial de 1850, conforme será mostrado em seguida.

O Eminente prof. Miguel Reale, por exemplo, Supervisor da Comissão Revisora e Elaboradora do Código Civil, criada em 1969 para rever o Código Civil -composta pelos juristas Agostinho de Arruda Alvim, José Carlos Moreira Alves, Sylvio Marcondes, Clóvis do Couto e Silva, Torquato Castro e Ebert Chamoun -, destacou, com muita insistência, o acolhimento de três princípios básicos do novo Código Civil, a saber: a eticidade, a socialidade e a operacionalidade ${ }^{43}$ Por eticidade o ilustre jurista pátrio quis designar, fundamentalmente, o respeito aos princípios enformadores ${ }^{44}$ da

4 A expressão é originária de um instituto do Direito Romano - o da laesio enormis -, na qual era suficiente, para a caracterização do vicio da vontade, que, numa compra e venda, a assimetria entre as prestações das partes contratantes fosse superior à metade do preço considerado justo. A duutrina moderna tem se utilizado, indistintamente, das expressões lesão ou estado de necessidade na designação do vício.

42 A E. prof?. Cláudia Lima Marques, em sua famosa obra (MARQUES, Claudia Lima. Contratos no Código de Defesa do Consumidor. 4. ed. São Paulo: Revista dos Tribunais, 2002. p. 671), assevera, com razão, que: "Poderiamos afirmar genericamente que a boa-fé é o princípio máximo orientador do CDC" (grifos da autora).

43 Veja-se, exemplificativamente, trecho do discurso do ilustre professor na cerimônia especial dedicada à sanção da Lei que institui o novo Código Civil, con a presença do então presidente da República Fernando Henrique Cardoso: "É com a responsabilidade que me advém da longa idade e de aturado estudo que posso assegurar, senhor Presidente, que vai ser sancionada uma Lei Civil que será da maior valia para o País, sobretudo em razão dos princípios de eticidade, socialidade e operabilidade que presidiram a sua elaboração"

44 Conforme já me pronunciei anteriormente (DE LUCCA, Newton. Direito do Consumidor: teoria geral da relação juridica de consumo. São Paulo: Ed. Quartier Latin, 2003. p. 62): “Alude-se na doutrina juridica, de forma praticamente unânime. a princípios informadores, grafado este último vocábulo com a letra "i" Mesmo em títulos de trabalhos publicados, de natureza acadêmica, já tive a ocasião de verificar essa preferência pela retro aludida grafia. Por exemplo (NERY JÚNIOR, Nelson. Os principios gerais do Código Brasileiro de Delesa do Consumidor. Revista de Direilo do Consumidor, São Paulo, n. 3, p. 44-77, set./dez. 1992), classifica os principios em "Informativos" e "Fundamentais". semeihantementc a Sperduti que alude a principios científicos, principios normativos e principios informativos.

Quando me utilizo da expressão, no entanto, o faço com a letra " $i$ ", pois entendo que os principios concebidos, sem embargo dos diferentes matizes existentes, em seu sentido filosófico, como "proposições diretoras de uma ciência às quais todo o desenvolvimento posterior dessa ciência deve estar subordinado — não dão informação de algo, mas antes dão forma (ó), isto é, enformam no sentido de moldarem ou mesmo de construírem uma forma (ô) preparada para a produçāo de algo. Afirmou 
probidade e da boa-fé que devem necessariamente presidir as relações jurídicas entre as pessoas, garantindo-se maior segurança às partes contratantes.

Temos, para nós, que esse repúdio ao normativismo asséptico ${ }^{45}$ do Direito Positivo terá sido a maior virtude do novo Código Civil brasileiro. "Ao elaborar o Projeto" - diz-nos o E. prof. Miguel Reale - "não nos apegamos ao rigorismo normativo, pretendendo tudo prever detalhada e obrigatoriamente, como se na experiencia juridica imperasse o principio de causalidade próprio das ciências naturais, nas quais, aliás, se reconhece cada vez mais o valor do problemático e do conjetural" ${ }^{46}$ acrescentando, pouco mais adiante, não ter prevalecido, no âmbito do Projeto, "a crença na plenitude hermética do Direito Positivo. sendo reconhecida a imprescindivel eticidade do ordenamento" 47

Quanto ao principio da socialidade, pode-se dizer, grosso modo, que ele diz respeito - ao contrário do que sucedia no Código Civil. de 1916, de caráter eminentemente individualista - ao aspecto marcadamente social de sua disciplina.

Nas palavras do grande jurisconsulto pátrio:

O 'sentido social' é uma das caracteristicas mais marcantes do Projeto, em contraste com o sentido individualista que condiciona o Código Civil ainda em vigor. Seria absurdo negar os altos méritos da obra do insigne Clóvis Beviláqua, mas é preciso lembrar que ele redigiu sua proposta em fins do século passado, não sendo segredo para ninguém que o mundo nunca mudou tanto como no decorrer do presente século, assolado por profundos conflitos sociais e militares. Se não houve a vitória do socialismo. houve o triunfo da 'socialidade', fazendo prevalecer os valores coletivos sobre os individuais, sem perda, porém, do valor fundante da pessoa humana. Por outro lado. o Projeto se distingue por maior aderência à realidade contemporânea, com a

(CARRIÓ, Genaro. Notas sobre Derecho y Lenguaje. 4. ed. Buenos Aires: Abeledo-Perrot, 1990. p. 209. 212), com inteiro acerto, a existência de pelo menos sete focos de significação para o que possa ser considerado um principio. Mas essa pluralidade de significados não desautoriza — antes, reforça - a conclusão de que, ao menos prevalecentemente, os princípios enformam em lugar de simplesmente informarem. Já (SOULA, Miriam de Almeida. A politica legislativa do consumidor no Direito comparado. Salvador: Nova Alvorada Ediçỏes, 1996. p. 21-22, após interessante citação de Henri de Page sobre o sentido da lei diante da vida. afirma, com acerto: "Coerente com essa lição do ilustre professor belga, que enxerga no Direito um fim social a preencher e com a tendência preduminante, segundo a qual o verdadeiro sentido de sua evolução é a proteção dos hipossuficientes econômicos e. em estágio mais evoluído, dos menos capacitados em geral, é que será analisada a politica legislativa que enformou a estruturação dos códigos de defesa do consumidor em diferentes sociedades em mudança." (negrito nosso)

4s Estamos nos valendo de uma expressào de (BOBBIO. Norberto. De senectute e altri scritti autobiografici. Turim: Einaudi, 1996. p. 86) ao referir-se à dificuldade de conciliar-se, entre outros, o formalismo asséptico de Kelsen cum o pragmatismo iluminista de Cattanio.

46 REAlE, Miguel. O Projeto do Novo Código Civil. 2. ed. ref. e atual. São Paulo: Saraiva, 1949. p. 8.

47 Id. Ibid., p. 9. 
necessária revisão dos direitos e deveres dos cinco principais personagens do Direito Privado tradicional: o proprietário, o contratante, o empresário, o pai de familia e o lestador. ${ }^{48}$

Ver-se-á, mais adiante, com especial ênfase, a disposição constante do art. 421 do NCC, que expressamente outorga realce à função social do contrato. Tal princípio não se encontra adstrito ao âmbito contratual, mas espraia-se, exemplificativamente. também para o terreno do Direito das coisas. ${ }^{49}$

Quanto ao principio da operacionalidade, quis o eminente professor referir-se à técnica legislativa utilizada no sentido de uma linguagem iscnta de dubiedades, tanto quanto possível precisa e atual, acessível a todos e de fácil compreensão. A aplicação da lei, por parte do juiz, torna-se bem mais flexível, outorgando-se-lhe a possibilidade de nova atitude epistemológica do julgador, conferindo-Ihe a lei o mais amplo poder de decidir, fazendo a justiça in concreto, em todas aquelas hipóteses em que houver indeterminação do dispositivo legal. Esse poder exige do magistrado, não apenas o conhecimento juridico - o qual, de resto, lhe é inerente -, mas, fundamentalmente, a prudência de saber discernir no "mundo da vida", ou no Lebenswelt de que nos falam os alemães, as circunstâncias peculiares de cada caso concreto. $^{50}$

Nas palavras do próprio jurista e filósofo Miguel Reale o princípio da operacionalidade significou. para os elaboradores do novo Código, que, "toda vez que tivemos de examinar uma norma juridica, e havia divergência de caráter teórico sobre a natureza dessa norma ou sobre a conveniência de ser enunciada de uma forma ou de outra, pensamos no ensinamento de Jhering, que diz que é da essência do Direito a sua

4. Diz o professor Reale. em seguida, que o empenho da Comissão foi no sentido de situar tais direitus e deveres no contexto da nova sociedade que emergiu de duas guerras universais, bem como da revolução tecnológica e da emancipação plena da mulher, sendo por tal motivo que ele propús que " $o$ "pátrio poder" passasse a denominar-se 'poder familiar', exercido em conjunto por ambos os côrijuges em razão do casal e da prole"

Ju Assinale-se que a função social da propriedade, erigida a principio da ordem econômica. de acordo com o inciso III do art. 170 da Constituição Federal brasileira forneceu a diretriz fundamental para o que consta dos $\S \S 1^{\circ}, 2^{\circ}, 3^{\circ}, 4^{\circ}$ e $5^{\circ}$ do art. 1.228. Quadra transcrever, nesse passo - pelo caráter amplamente revolucionário de ambos para o Professor Migucl Reale - os $\$ \$ 4^{\circ}$ e $5^{\circ}$ desse artigo 1.228, verbis:

"\$ $4^{\circ}$ - $U$ proprietário também pode ser privado da coisa se o imóvel reivindicado consistir em extensa área. na posse ininterrupta e de boa-fé, por mais de cinco anos, de considerável nimero de pessoas, e estas nela houvirem realizado. em conjunı ou scparadamente. obras e servicos cunsiderados pelo juiz de interesse social e econômico relevante.

$\$ 5^{\circ}$ - No caso do parágrafo antecedente, o juiz fixará a jusı indenização devida au proprietário: pago o preço, valerá a sentença como título para o registro do imóvel em nome dos possuidores" Conforme oportunamente salientado pelo professor Miguel Reale, esse $\S 5 .^{\circ}$ outorgou ao magistrado verdadeiro poder de expropriação, constituindo uma autêntica novidade na ordenação juridica pátria.

so Escusava dizer, portanto, que a expressão utilizada no texto principal não se confundc com o sentido de estado pré-categorial da existência, tal como o definia Husserl. 
razoabilidade: o Direito é feito para ser executado; Direito que não se executa -já dizia Jhering na sua imaginação criadora - é como chama quc não aquece, luz que não ilumina; o Direito é feito para ser realizado; é para ser operado" st

Gostaríamos de trazer à balha, neste momento, os arts. 130 e 131 do velho e revogado Código Comercial de 1850, segundo os quais:

Art. 130. As palavras dos contratos e convenções mercantis devem inteiramente entender-si segundo o costume e uso recehido no comércio, e pelo mesmo modo ' sentido por que os negociantes se costumam explicar; posto que entendidas de outra sorte possam significar coisa diversa.

Art. 131. Sendo necessário interpretar as cláusulas do contrato, a interpretação, alèm das regras sobreditas, será regulada sobre as seguintes buses:

1. a inteligência simples e adequada, que for mais conforme à boa-fé, e ao verdadeiro espirito e natureza do contrato, deverá sempre prevalecur à rigorosa e restrita significação das palavras;

2. as cláusulas duvidosas serão entendidas pelas que o não forem, e que as partes iverem admitidn; c as antecedentes e subseqüentes, que estiverem em harmonia. explicarão as ambiguas;

3. o fato dos contraentes, posterior ao contrato, que tiver relação com o objero principal, será a melhor explicação da vontade qui as partes tiveram no ato da celebração do mesmo contrato;

4. o uso e prática geralmente observada no comércio nos casos da mesma natureza, e especialmente o costume do lugar onde o contrato deva ter execuçâo, prevalecerá u qualquer inteligência em contrário que se pretenda dar às palavias;

5. nos casos duvidosos. que não possam resolver-se segundo as bases estabelecidas, decidir-se-á em favor do devedor:

Sempre entendemos - e o repetimos à exaustão nas numerosas palestras pronunciadas a respeito da matéria - que tais dispositivos do nosso velho Código Comercial, editado ainda no tempo do Brasil Imperial, já continham claramente a adoção

51 Cf. REALE, Miguel. O Projeto do Novo Código Civil. 2. ed. ref. e atual. São Paulo: Saraiva 1999. p. 10. 
da chamada boa-fé objetiva, ${ }^{52}$ muito tempo depois consagrada pelo Código de Defesa do Consumidor.

Também no Esboço, de Teixeira de Freitas. a boa-fé já não era mais considerada como algo meramente relacionado à psicologia dos contratantes - boa-fé subjetiva, haurida do velho Direito Romano, tida como princípio de hermenêutica ${ }^{53}$ mas como norma de conduta das partes, conforme se deduz do art. 1.954, no parágrafo sobre os efeitos dos contratos, in verbis:

52 A doutrina brasileira distingue a boa-fé subjetiva da boa-fé ohjetiva. Ao fazer uma comparaçāo entre essas duas modalidades, o E. Prof. (AZEVEDO, Antônio Junqueira de. A boa-fé na formação dos contratos. Revista de Direito do Consumidor, São Paulo, n. 3, p. 78-87, set./dez. 1991), ao tempo em que ainda vigorava o Código Civil de 1916, assinalou, com precisão: "Em assuntos específicos, como contrato de seguro, contrato de sociedade (art. 1404), aquisição a non domino (art. 622), pagamento indevido (art. 968), posse (art. 490 e ss.), usucapião (art. 500 e ss.), construçào e plantação (art. 546 e ss.) dívida de jogo (art. I.677) etc., o próprio Código Civil prevê a boa-fé para certas consequiências jurídicas. Trata-se, porém, em todos esses casos, salvo os dois primeiros (seguro e sociedade), da chamada boa-fé subjetiva, isto é, daquele estado interior ou psicológico relativo ao conhecimento. ou desconhecimento. e á intenção, ou falta de intunção, de alguém. Vale dizer, ainda, que, atualmente. como conseqüíncia da mudança de mentalidade, a recente lei de proteçào ao consumidor, que, por sua amplitude. é denominada 'Código de Proteção ao Consumidor' (Lei n. 8.078/90) tem o princípio da boa-fé refletido em inúmeros de seus artigos. Aqui, trata-se, na verdade, de boa-fé objetiva que interessa à formação do contrato, isto é, como regra (objeliva) de conduta"

i3 A expressão hermenêutica parece derivar de Hermes. mensageiro da palavra e da vontade de Zeus, na Mitologia Grega. Permito-me recordar, como já o fiz anteriormente (DE LUCCA, Newton. Direitn dn Consumidor. São Paulo: Editora Quatier I atin, 2003. p. 479 e ss.) uma das versõcs daquele relato mitológico, dada a perquirıção da origem etimológica do vocábulo hermenêutica: Os deusus do Olimpo haviam encarregado os irmãos, Prometeus e Epimeteus, da criação dos seres vivos sobre a Terra. Filhos do Titã lápetos e de Têmis, assim repartiram suas tarefas: enquanto o primeiro cuidaria da criação do homem, o segundo distribuiria aos animais as qualidades que deveriam ter. Além disso, Prometeus encarregara-se de verificar o resultado do trabalho de seu irmão.

E Prometeus, usando barro, fez o primciro homem. Epimeteus, a seu tumo, distribuiu as qualidades aos animais de sorte a salvaguardar-lhes idêntica possibilidade de sobrevivência. Aos animais dotados de velocidade. faltar-lhes-ia a força. Aos contemplados com esta, minguar-lhes-ia a velocidade. e todos os atributos foram sendo distribuidos de maneira tal que o equilibrio vital entre todos os animais ficasse preservado.

Houvera se consumado, assim, a primeira imprevidência de Epimeteus. Esgotadas todas as qualidades possíveis com os animais irracionais, o que restaria ao homem fazer pela sua sobrevivencia?

Prometeus, extremamente dotado de ousadia, de pertinácia e disposto a lutar pelos homens, resolveu subir ao Olimpo para tentar subtrair dos deuses os atributos superiores que possuiam. E logrou obter as técnicas da sobrevivência, atribuindo-lhas aos homens. Como se a ousadia já não fossc o bastante, na partilha das vítimas dos sacrifícios oferecidos, Prometeus enganou Leus, ardilosamente, tazendo com que este escolhesse as piores porções para os deuses, ficando as melhores com os homens...

Revoltado, Zeus ordenou a Héfaistos que fizesse uma mulher, lambém de barro (que se chamou Pandora), com a missão de castigar Prometeus. Enquanto a deusa Alena, filha de Zeus e de Métis, com um sopro transmitia vida a Pandora, a esta eram atribuidos todos os demais encantos pclos outros deuses. derivando dai a significação de seu nome, Pandora, que significa "todos os dons". Hermes, no entanto, encarreguu-se de agregar-lhe a lisonja e a astúcia.

Como Prometeus prudentemente previra os problemas que Pandora traria, ela foi enviada a scu irmão Epimeteus - "o que pensa depois" - que não vacilou em aceitá-la. E a famosa "caixinha de Pandora", com todo o seu cortejo de maleficios, acabou se espalhando entre os homens... 
Os contratos devem ser cumpridos de boa-fé, pena de responsabilidade pelas faltas (arts. 844 e 847), segundo as regras do art 881. Eles obrigam não só ao que expressamente se tiver convencionado, como a ludo que. segundo a natureza do contrato, for de lei, eqüidade, ou costume.

Dificil não se reconhecer que, em tal caso, já se previa o que hoje se denomina boa-fé objetiva. De toda sorte, é claro que os avanços obtidos com o CDC, de 1990, e com o NCC, de 2002, são consideráveis, nesse particular.

$\mathrm{O}$ Eminente ministro José Carlos Moreira Alves, em primoroso artigo intitulado A boa-fé objetiva no sistema contratual brasileiro — jurista que, por diversas vezes, assumiu posição bastante crítica em relação ao Código de Defesa do Consumidor - reconheceu a importância e o próprio pioneirismo desse diploma pelo fato de ele ter consagrado, expressivamente, a boa-fé objetiva. Embora longo, vale a pena transcrever o seguinte trecho do ilustre jurista pátrio:

Mais recentemente foi editado no Brasil, em observância a
dispositivo constitucional, o Código de Proteção e defesa
do Consumidor (Lei n. 8.078 , de 11 de setembro de 1990),
onde há direta referência à boa-fé em dois dispositivos: no
art. $4^{\circ}$. III. e no art. 51 , IV. No primeiro deles se preceitua
que um dos princípios da Politica Nacional das Relações de
Consumo é a 'harmonização dos interesses dos
participantes das relações de consumo e compatibilização
da proteção do consumidor com a necessidade de

Mesmo dotados das técnicas para produzir os meios de sua subsistência, revelaram-se os homens incapazes de conviver harmonicamente entre si, destituidos que eram da arte politica.

Segundo consta, Zeus jamais teria perdoado a Prometeus. Fosse por causa desse episódio da atribuição indevida de qualidades aos homens. fosse porque Prometeus, mesmo acorrentado a um rochedo solitário no montc Cáucasos - sofrendo de maneira atroz com uma águia que the vinha devorar diariamente o figado - recusava-se a revelar o segredo de qual seria o filho de Tétis que poderia representar ameaça ao dominio de Zeus, o fato é que Prometeus terminou despejado num abismo, juntamentc com as Oceanides, que resolveram reconfortá-lo e compartilhar de seu destino.

Da trilogia de F́squilo, efetivamente. muita coisa se perdeu. Há fragmentos de uma das peças em que, no início de uma cena, aparece Prometeus voltando a ver a luz. passados trinta mil anos.

Quanto ao destino da espécie humana, porém. consta que Zeus se compadeceu da aflitiva situação de guerra vivida pelos homens e. tcmendo pela sua sobrevivència, resolve enviar Hermes, na qualidade de scu mensageiro pessoal. com o propósito de atribuir aos seres humanos os sentimentos de justiça e de dignidade pessual, sem os quais turna-se praticamente impossivel a subsistència de uma civilização, daqui se originando, como já se disse, a provável significação do que hoje se denomina Hirmenéutica.

Antes de partir para sua missào. Hermes interrogou Zeus se deveria atribuir aus humens o dom da ante política na mesma proporção em que houvera sido a eles distribuida, anteriormente. a habilidade técnica. isto é, se bastaria que um grupo deles fosse aquinhoado coln o dom a ser utilizado $\mathrm{cm}$ beneficio de toda a culetividade. Peremptório tería sido 7.eus em sua resposta: todos os homens deveriam conhecer e scr instruídos na arte politica - e não apenas alguns deles - sob pena de. à mingua da necessária concórdia e harmonia entre elcs, ocorrer a própria extinção da raça humana. Ainda mats do que isso, preconizou Zeus: Hermes deveria instituir a pena de morte para aqueles que não soubessem praticar a ane de governar. comparando-os a uma espécie de doença infecciosa de toda a coletividade. 
desunvolvimento econômico e tecnológico. de modo a viabilizar os principios nos quais se funda a ordem econômica (art. 170 da Constituição Federal), sempre com base na BOA-FÉ e equilibrio nas relações entre consumidores e fornecedores' E no segundo sc dispõe que são nulas de pleno Direito, entre outras. as cláusulas contratuais relativas ao fornecimento de produtos e serviços que 'estabeleçam obrigações consideradas iniquas, abusivas, que coloquem o consumidor em desvantagem exagerada, ou sejam incompativeis com a BOA-FÉ ou a eqüidade. No primeiro desses dois dispositivos, a boa-fé se apresenta como cláusula geral, que permite a atividade criadora do juiz ainda que limitada, o que, no entanto, não ocorre com o segundo, em que se contigura ela como conceito indelerminado. porque o legislador não deixou an juiz que, com a sua aplicação, the extraísse conseqüências. mas, ao contrário, as prefixou ao determinar a nulidade de pleno direito das cláusulas que estabeleçam obrigações iníquas ou abusivas. É. certo, porém, que, deixado de lado o art. $131,1^{\circ}$, do Código Comercial por não ter tido, a não ser recentemente, maior influência, a esse respeito, na doutrina e na jurisprudência, foi o Código de Defesa e Proteção do Consumidor o primeiro diploma legal brasilciro que consagrou expressivamente a boa-fé objetiva, além de impor em vários de seus dispositivos deveres secundários que dela decorreriam se não tivessem sido expressos, como, a título de exemplo, os de formação, de segurança, de veracidade, de lealdade e de probidade (artigos $8^{\circ}, 9^{\circ}$ $10,31.36$ e 37 ).(grifos nossos)

A E. prof ('láudia L.ima Marques, em sua obra já citada anteriormente, ${ }^{54}$ ao cuidar da imposição do princípio da boa-fé objetiva, destacou:

Como no paradigma para as relações contratuais de consumo de nossa sociedade massificada, despersonalizada e cada vez mais complexa, propõe a ciência do Direito o renascimento ou a revitalização de um dos principios gerais do Direito há muito conhecido e sempre presente desde o movimento do Direito natural: o princípio geral da boa-fé. Este princípio ou novo 'mandamento' (gebot) obrigatório a todas as relações contratuais na sociedade moderna, e não só as relações de consumo, scrá aqui denominado de principio da boa-fé objetiva para destacar a sua nova interpretação e função.

is Cf. MARQueS, Cláudia Lima. Contratos no Código de Defesa do Consumidor. 4. ed. São Paulo: Revista dos Tribunais, 2002. p. 180-207. onde a autora analisa minudente e exaustivamente esse princípio da boafé objetiva. 
Pode-se dizer, de certo modo, que essa justa reivindicação da citada professora para que as novas funçōes da boa-fé ultrapassem as fronteiras das relações de consumo, foi atendida pelo art. 113 do novo Código Civil pátrio. Ele torna a boa-fé objetiva, com efeito, um principio não mais apenas do Direito Comercial (como já o era, segundo o nosso entendimento) e do Direito do consumidor, mas da ordenação ${ }^{\varsigma s}$ jurídica como um todo, pela função central que nela o Código Civil inquestionavelmente exerce. ${ }^{56}$ Tal princípio é reforçado mais adiante, conforme será visto, no exame do art. 422, ocasião cm que nos permitiremos fazer maiores aprofundamentos doutrinários

55 À palavra ordenamento juridico, absolutamente corrente na doutrina brasileira, temos preferido, para fugir ao injustificável italianismo, ordenaç̧ào juridica. mais consentânea com o idioma Portuguès. conforme jà destacado pela autorizada voz do gramático Napoleão Mendes de Almeida, tendo sido colocada em itálico. no texto principal, de forma deliberada. a lim de propiciar o presente esclarecimento.

56 A afirmaçāo constante do texto principal precisa sur entendida cum gramus salis... Ninguém desconhece, é claro, a progressiva perda dessa função centralizadora. outrora desempenhada pelo Código Civil, desde o famoso Código de Napoleão, de 1804. A doutrina é abundante a respeito dessé fenómeno, podendo ser citados, entrc outros. (LORENZETTl. Ricardo Luis. Fundamentos do Direito Privado. Sào Paulo: Revista dos Tribunais, 1998. p. 45), verbis: "O Direito Civil atual não se funda em uma só lei codificada: ao contrário, há muitas leis para distintos setores de atividade e de cidadãos. A igualdade legislativa e um sonho esquecido. na medida em que as normas juridicas são particularizadas e com efeitos distributivos precisos. A idéia de ordenar a sociedade ficou sem efeito a partir da perda do prestigio das visóes totalizadoras; n Direito Civil se apresenta antes como estrutura defensiva do cidadào e de coletividades do que como "ordem" social. O Código divide sua vida com outros Códigos, com microssistemas juridicos e com subsistemas. O Código perdeu a centralidade, porquanto ela se desloca progressivamente. O Código i substituido pela constitucionalização do Direito ("ivil, e o ordenamento codificado pelo sistema de normas fundamentais. A explosāo do ('ódigo produziu um fracionamento da ordem juridica. semelhante ao sistema planetário. Criaram-sc microssistemas juridicos que. da mesma forma como os planetas, giram com autonomia própria, sua vida é independente, o Código é como o sol, ilumina-os. colabora em suas i idas. mas já nào pode incidir diretamente sobre eles.": (TEPEDINO, Gustavo José Mendes. Problemas de Direito Civil Constitucional. Introdução: Código Civil, os Chamados Microssistemas e a Constituição: Premissas para uma Reforma Legislativa. In: PROBLEMAS de Direito Civil. Rio de Janeiro: Ed. Renovar. 2000. p. 5): "Esse longo percurso histórico. cujo itinerário não se poderia aqui palmilhar, caracteriza o que se convencionou chamar de processo de descodificaçào do Direito Civil, com o deslocamento do centro de gravidade do direito privado, do Código Civil, antes um corpo legislativo monolitico, por isso mesmo chamado de monossistema, para uma realidade fragmentada pela pluralidade de estatutos autônomos. Em relaçào a estes o Código Civil perdeu qualquer capacidade de influéncia normativa, configurando-se um polissistema. caracterizado por um conjunto de leis tidas como centros de gravidade autônomos, c chamados, por conhecida corrente doutrinária, de microssistemas." Merecem destaque deveras especial. por razōes de ordem várias, duas liçōes sobre o tema: a primeira delas, de (IRTI, Natalino. L'età della decodificacazione. 4. ed. Milão: Giuffré, 1979. p. 33), segundo a qual: "O ("ódigo Civil perdeu o caráter de centralidade no sistema das fontes: não è mais sede das garantias do individuo, porque constam da Constituiçào, nem dos principios gerais, visto que expressos, por singulares categorias de bens ou classes de sujeitos, em leis autonomas". A segunda lição é do saudoso jurista baiano (GOMES. Orlando. A Agonia do Direito Civil: Conferència proferida no Encontro Nacional de Mestres de Direito Civil. Ed. Ciência Juridica p. 74-76): "Essas e tantas outras leis especiais distinguem-se do Código Civil e o enfrentam, constituindo microssistemas que introduzem novos principios de disciplina das relaçòes juridicas a que se dirigem. Sua proliferaçào ocasionou a cmersào de nor as logicas setoriais. Caracterizam-sc, com efeito, pela especialidade e pela diferenciação e concretude. Promulgados para a regéncia peculiar de determinadas classes de relações juridicas ou para a proteção particular de uma categoria de pessoas. alguns desses diplomas legais apanham institutos antes integrantes do Código Civil, enquanto outros atendem a novits necessidades, sem regulumentação anterior". concluindo que "A multiplicação das leis 
sobre a matéria.

Fxaminemos, agora, o art. 423. Eis o seu texto:

Quando houver no contrato de adesão cláusulas ambiguas ou contraditórias, dever-se-á adotar a interpretação mais favorável ao aderente.

Norma semelhante a esta pode ser encontrada, exemplificativamente, no art. 1.401 do Código Civil peruano, verbis:

Las estipulaciones insertas en cláusulas generales de contratación o en formulários redactados por una de las partes se interpretarán, em caso de duda, a favor de la outra.

Guillermo Lohmann Luca de Tena afirma, a nosso ver com inteiro acerto, que: "Se trae a colación este articulo a este lugar pue responde a un principio que informa no solo los contratos sino todos los negócios bilaterales: la interpretación de declaraciones recepticias oscuras no debe favorecer a la parte que hubiera motivado la oscuridad" 57

Essa disposição do art. 423 do novo Código Civil brasileiro figurava, a princípio, no corpo do anteprojeto, apenas na parte relativa aos contratos de seguros. Tratava-se do art. 803 do anteprojeto de Código Civil. Foi por causa de uma oportuníssima sugestão do E. prof. Fábio Konder Comparato que ela foi transportada, como de rigor, para a parte geral dos contratos.

Abstemo-nos, por ora, de maiores considerações a respeito desse artigo em face do que pretendemos desenvolver mais adiante, ao cuidarmos das normas de interpretação no Código de Defesa do Consumidor brasileiro, especificamente daquela enunciada no art. 47, segundo a qual as cláusulas contratuais - todas elas e não apenas as ambiguas e contraditórias — devem ser interpretadas em favor do consumidor.

Vejamos, então, conforme foi dito linhas atrás, aqueles outros quatro artigos $(156,157,421$ e 422) do novo Código Civil, os quais, ainda que não se refiram,

especiais está causando a agonia do Código Civil. Quebrada a unidade do sistema, deixou este de condensar e exprimir os princípios gerais do ordenamento" Cf. por derradeiro, o luminoso estudo de ASCARELLI, Tullio. A idèia de Código no Direito privado e a tarefa da interpretação. In: PROBLEMAS das Sociedades Anônimus e Direito Comparado. São Paulo: Saraiva, 1969. Ascarelli sempre demonstrou ter constante preocupação com as tarefas da interpretação - sempre poderosamente criadoras para ele levando-o a comparar os caminhos do Direito aos de Antígone e de Pórcia, na peça esculpida pelo gênio dc Sófocles.

57 Cf. LOHMANN LLCA DE TENA, Guillermo. La Interpretación de la ley y de los actos juridicos en el derecho peruano, in Interpretación de los contratos. Revista de Derecho Comparado. Buenos Aires. n. 3. p. 84, fev. 2001. 
propriamente, a normas de interpretação contratual, encerram figuras nas quais o papel da interpretação a partir de principios ganha especial relevo.

Comecemos pelo art. 156. Por ele está dito que:

Configuru-se o estado de perigo quando alguém, premido da necessidade de sulvar-se, ou a pessoa de sua familia, de grave dano conhecido da outra parte, assume obrigação excessivamente onerosa.

Parágrafo Único - Tratando-se de pessoa não pertencente à família do declarante, o juiz decidirá segundo as circunstâncias.

Verifica-se, por esse artigo - e, igualmente, pelo art. 157, a seguir comentado - que se está diante daquilo a que a doutrina designa por defeitos do negócio jurídico e que correspondem, respectivamente, ao stato di pericolo e stato di bisogno, do Código Civil italiano. ${ }^{58}$

Seja no estado de perigo, seja no da lesão, não se está diante de erro da declaração de vontade por parte da vítima. Trata-se, antes, de uma deformação ocorrida na declaração de vontade desta.

Como bem esclarece o prof. Carlos Alberto Bittar, nosso saudoso companheiro de USP, ao tratar do instituto jurídico da lesão, representa ela um "vicio consistente na deformação da declaração por fatores pessoais do contratante, diante de inexperiência ou necessidade, explorados indevidamente pelo locupletante." $" 59$

Também o E. prof. Humberto Theodoro Júnior é preciso em sua explicação a respeito dessas duas figuras:

Em todas elas, não há propriamente erro da vitima no declarar a vontade negocial, o que se passa é o quadro de perigo enfrentado no momento do aperfeiçoamento do negócio que coloca a pessoa numa contingência de necessidade premente de certo bem ou valor e, para obtêlo, acaba ajustando preços e condiçōes desequilibradas. $\mathrm{O}$ contrato, em tais circunstâncias, se torna iniquo, porque uma das partes se aproveita da conjuntura adversa para extrair vantagens injustas à custa da necessidade da outra.".!

E prossegue o citado jurista:

No estado de perigo, o que determina a submissão das vítimas ao negócio iniquo ¿ o risco pessoal (perigo de vida

$58 \mathrm{Cr}$. arts. 1.447 e 1.448 .

s9 Ci. BITTAR, Carlos Alberto. Curso de Direito Civil. Rio de Janeiro: Forense Universitária, 1999. v. 1. p. 155.

so Cf. THEODORO JíNIUR. Humberto. Comentarios ao Novo Código (ivil. vol. Ill, tomo I, obra coletiva coordenada pelo ministro Sálvio de Figueiredo Teixeira, Ed. Forense, 1. ed.. Rio de Janeiro, 2003. p. 204. 
ou de grave dano à saúde ou à integridade física de uma pessoa). Na lesão (ou estado de necessidade), o risco provém da iminência de danos patrimoniais, como a urgência de honrar compromissos, de evitar a lalência ou a ruina dos negócios. (grifos do Autor) ${ }^{61}$

O novo Código Civil brasileiro, a par dos comentários que estão sendo feitos pela doutrina especializada, já foi objeto de três Jornadas de Direito Civil, organizadas pelo Centro de Estudos Judiciários do Conselho da Justiça Federal, em Brasilia: a primeira, dos dias 11 a 13 de setembro de 2002; a segunda, em 2003; e a terceira, dos dias $1^{\circ}$ a 3 de dezembro de 2004, todas sob a primorosa coordenação pelo E. min. Ruy Rosado de Aguiar Jr. Nas I e III Jornadas houve a aprovação de Enunciados por parte dos Grupos de Trabalho, sendo oportuno mencionar, neste momento, aqueles que se referem aos artigos ora mencionados no presente trabalho.

No que se refere a esse art. 156, na terceira Jornada, recentemente realizada, foi aprovado um Enunciado, do seguinte teor:

Ao estado de perigo (art. 156) aplica-se, por analogia, o disposio 110 \& $2^{\circ}$ do art. 157.

Vejamos, a seguir. o art. 157, segundo o qual:

Ocorre a lesão quando uma pessoa, sob premente necessidade, ou por inexperiência, se obriga a prestaçâo manifestamente desproporcional ao valor da prestação oposta.

$\S 1^{\circ}$ Aprecia-se a desproporção das prestações segundo os valores vigentes ao tempo em que foi celebrado o negócio juridico.

$\S 2^{\circ}$ Não se decretará a amulação do negócio, se for oferecido suplemento suficiente, ou se a parte favorecida concordar com a redução do proveito. ${ }^{62}$

Enquanto o anterior art. 156 cuidou do estado de perigo, esse art. 157 contemplou a ligura da lesão.

Vì-se, por ele, que houve notória evolução no Dircito brasileiro, pois o Código Civil de 1916 não contemplara, quer a figura do estado de perigo, quer a da lesão. Clóvis Beviláqua, ${ }^{63}$ por exemplo - possivelmente influenciado pelo pensamento positivista predominante à época - sustentara que "os illimos projetos de Código Civil

\footnotetext{
6! THEODORO IÚNIOR. Humberto. Comentários ao Novo Código Civil, cit.. p. 204.

62 Além do jả mencionado art. 1.448 do Código Civil italiano - fonte inspiradora do nosso NCC -, trataram igualmente da lesão, entre outros: o Código Civil francês (arts. 1.305 e 1.313 ), o portuguĉs (arts. $282^{\circ} \mathrm{e}$ $283^{\circ}$ ), o argentino (art. 954) e o peruano (arts. 1.447. 1.449. 1.450 e 1.451).

63 Cf. BEVILȦQUA. Clóvis. Teoria Geral do Dirito (ivil. 5. ed. Rio de Janeiro: Francisco Alves, 1929. \$ 56.
} 
Brasileiro somente aludiam à lesão nas partilhas, porque nesta domina a lei da mais plena igualdade entre os herdeiros, e o (ódigo, afinal, eliminou, inteiramınte, esse instituto."

Manuel Inácio Carvalho de Mendonça, ${ }^{\text {th }}$ magistrado federal aposentado, na mesma estcira de Clóvis, considerou o instituto da lesão "decadente e antipático às legislações modernas" alegando que não o haviam contemplado "os Códigos da Holanda, o portuguès, o argentino, o espanhol, o suiço das Obrigações, o de Montenegro, o de Zurique, o alemão e até mesmo alguns que copiam fielmente o francès, tal como o Haiti" Concluiu no sentido de que "nosso Código Comercial só admite rescindir um contrato por lesâo quando esta é acompanhada de erro. dolo ou simulação"

Não prevaleceu, no Brasil, no entanto, tal entendimento. No âmbito da legislação consumerista, foi a lesão combatida em vários dispositivos do Código de Defesa do Consumidor. Vale a pena transcrever o texto de alguns dispositivos desse diploma legal, especialmente o do art. $6^{\circ}$ inciso $\mathrm{V}$; o do art. 39. inciso $\mathrm{V}$; o do art. 51. inciso IV e o desse mesmo artigo 51 , em seu $\S 1^{\circ}$, inciso III.

Diz o primeiro deles:

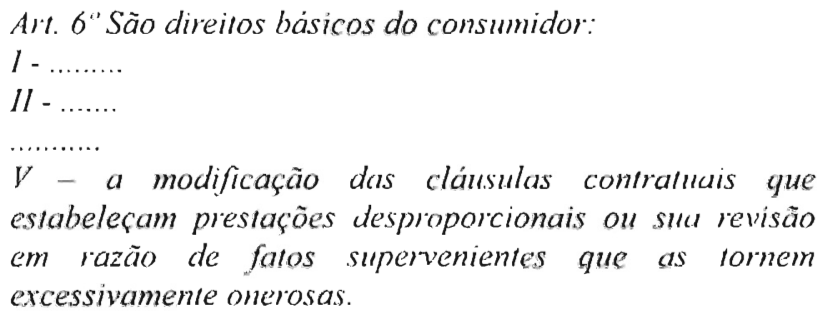

Dispõem o art. 39 e o seu inciso V:

É vedado ao fornecedor de produtos ou serviços dentre outras práticas abusivas: ${ }^{65}$

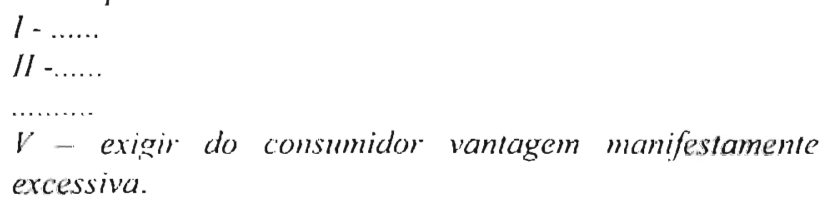

Com relação ao art. 51, estabelecem o caput do mesmo e o seu inciso IV:

\footnotetext{
at Cl. MENDONÇA. Manuel Inácio (arvalho de. Doutrina e pratica das obrigações ou tratado geral dos direitos de crédito. 4. ed. Rio de Janeiro: Forense. 1956. v. 2, n. 582. p. 219.

65 Redação dada pela Lei n. 8.884, de 11 de junho de 1994.
} 
São nulas de pleno direito, entre outras, as cláusulas contratuais relativas uo fornecimento de produtos $e$ serviços que:

I $\ldots . .$.

$I I-\ldots$.

IV - estabeleçam obrigações consideradas iniquas, abusivas, que coloquem o consumidor em desvantagem exagerada, ou sejam incompativeis com a boa-fé ou a equiiidade.

Por derradeiro, cumpre verificar a complementação de tais disposições feita pelo inciso III, do $\S 1^{\circ}$ desse mesmo artigo $5 \mathrm{I}$, verbis:

$\S l^{\circ}$ Presume-se exagerada, entre outros casos, a vantagem que:

1 - ....

$I I-\ldots$.

III - se mostra excessivamente onerosa para o consumidor, considerando-se a natureza e conteudo do contrato, o interesse das partes c'outras circunstâncias peculiares ao caso.

O alcance de tais dispositivos. no âmbito das relações de consumo, é enorme.

Nota-se que as cláusulas abusivas são fulminadas de nulidade absoluta pelo Código de Defesa do Consumidor brasileiro, valendo dizer, em conseqüência - e em face do caráter de ordem pública de toda a matéria nele constante ${ }^{66}$ - que ela jamais poderá ser atingida pelo fenômeno da preclusão. Assim sendo, independentemente de ser invocada pela parte no processo, a qualquer tempo e seja o grau de jurisdição que for, terá o magistrado o dever de declará-la de ofício. ${ }^{67}$

De toda sorte, é claro que o instituto da lesão, agora adotado também pelo NCC de 2002, representa um grande avanço, pois amplia consideravelmente o seu campo de aplicação, já que não está mais restrito a uma relação juridica entre desiguais (o fornecedor e o consumidor), mas também entre aqueles que, em princípio, são considerados iguais na órbita civil...

${ }_{66} \mathrm{O}$ art. $1^{\circ}$ do CDC dispòe: "O presente Código estabelece normas de proteção ¿' defesa do consumidor. do ordem pública e interesse social, nos termos dos arts. $5^{\circ}$, inciso XXXII, 170, inciso V. da Constinuição Federal c arı. 48 de suas Disposiçōes Transitórias". (grifos nossos)

$67 \mathrm{Cf}$, em idêntico sentido, a conclusāo do Prof. NERY JÚNIOR, Nelson. Código Brasileiro de Defesa do Consumidor comenta pelos autores do unteprojeto. 4. ed. Rio de Janeiro: Forense Universitária, 1995. p. 402: "Sendo matéria de ordem publica (art. $1^{\circ}, C D C$ ), a mulidade de pleno Direito das cláusulas abusivas nos contratos de consumo não é atingida pela preclusão. de modo que pode ser alegada no processo a qualquer tempo e grau de jurisdição. impondo-se ao juiz o dever de promunciá-la de oficio." 
A III Jornada de Direito Civil, há pouco referida, aprovou dois Enunciados a respeito desse art. 157. O primeiro deles está vazado nos seguintes termos:

Em atenção ao principio da conservaçâo dos contratos, a verificação da lesão deverá conduzir, sempre que possivel, à revisão judicial do negócio juridico e não à sua anulação, sendo dever do magistrado promover o incitamento dos contratantes a seguir as regras do art. 157, § 2", do Código Civil de 2002.

O segundo desses Enunciados diz:

A lesão de que trata o art. 157 do Código Civil não exige dolo de aproveitamento.

Passemos, agora, ao art. 421. Nele está dito: "A liberdade de contratar será exercida em razão e nos limites da função social do contrato"

Este dispositivo - igualmente saudado com entusiasmo pela doutrina brasileira - mereceu a autorizada crítica do E. prof. Antonio Junqueira de Azevedo, vazada em termos verdadeiramente irrespondíveis. ${ }^{68}$ Tento fazer um resumo, ainda que grosseiro, da crítica feita pelo ilustre professor, que considerou o dispositivo insuficiente, deficiente e calcado em paradigma anterior à realidade contemporânea.

Uma das insuficiências do artigo decorreria do periodo a que as partes estariam obrigadas a guardar os principios da probidade e da boa-fé: somente naquele que vai da conclusão à execução. Ora, tanto na fase pré-contratual quanto na póscontratual esses princípios deveriam estar presentes...

Quanto às deficiências, explica o citado jurista que existe uma tríplice função para a cláusula geral da boa-fé no âmbito contratual ou, segundo as suas próprias palavras, "porque justamente a idéia é ajudar na interpretação do contrato, adjuvandi. suprir algumas das falhas do contrato, isto é, acrescentar o que nele não está incluído, supplendi, e eventualmente corrigir alguma coisa que não é de direito no sentido de justo, corrigendi" concluindo que apenas a primeira está presente no artigo, faltandoIhe as outras duas, já amplamente previstas em termos de Direito comparado.

Finalmente, quanto ao paradigma ultrapassado adotado pelo novo Código Civil brasileiro, observa o prof. Junqueira que o diploma "infelizmente volta a insistir na presença do juiz para muita coisa inútil, como alguns casos de anulação e rescisão contratual" concluindo, na oportunidade, que "o projeto está no paradigma do estado inchado"

68 Cf. A7EVEDO, Antônio Junqueira de. Insuficiências, deficiências c desatualização do Projeto de Código Civil na questão da boa-fé objetiva nos contratos. Revisıa Trimestral de Direito Civil, Rio de Janeiro, v. I. n. 1, p. 3-12, jan./mar. 2000. 
Relativamente ao art. 421, a I Jornada aprovou os seguintes Enunciados, de n. 21, 22 e 23, verbis:

21 - A funçâao social do contrato, prevista no art. 421 do novo Código Civil, constitui cláusula geral, que impõe a revisão do principio da relatividade dos efeitos do contrato $\mathrm{em}$ relação a terceiros, implicando a tutela externa do crédito.

22 - A função social do contrato, prevista no art. 421 do novo Código Civil, constitui cláusula geral que reforça o principio da conservação do contrato, assegurando trocas itteis e justas.

23 - A função social do contrato, prevista no art. 421 do novo Código ("ivil, nào elimina o princípio da autonomia contratual, mas atenua e reduz o alcance desse principio, quando presentes meta-individuais ou interesse individual relativo à dignidade da pessoa humana.

Trata-se, como se purcebe, de um esforço interpretativo feito no sentido de tentar explicar o sentido e o alcance das disposições no novo ('ódigo.

Em pronunciamento feito na Ouvidoria Parlamentar da Câmara dos Deputados, no dia 4 de junho de 2002, tivemos a oportunidade de tecer as seguintes considerações a respeito da matéria:

Um dos tópicos que estão a merecer atenção especial, por parte desta douta Ouvidoria, diz respeito à questão da função social do empresário. Nenhum jurista de nomeada ousaria discordar, ao que suponho, da necessidade de pôr em realce essa função.

Afinal de contas, o parágrafo único do art. 116 de nossa Lei n. 6.404, de 15 de dezembro de 1975, disciplinadora da sociedade por ações, já dispusera de forma deveras lapidar sobre o tema, conforme vimos há pouco.

Assim, nessa linha de raciocínio, poder-se-ia sugerir a inclusão de um $\S 1 .^{\circ}$ ao atual art. 966 (transformando-se o parágrafo único em $\S 2^{\circ}$ ), do seguinte teor :

§ l. 'O exercicio da atividade empresarial, para ser' legítimo. deve cumprir; necessariamente, a sua função social.

Se é verdade que o art. 421 do Código Civil de que se cuida, como disposição geral dos contratos, deve ser entendido como aplicável também às sociedades - já que nestas se reconhece a natureza jurídica eminentemente contratual, ainda que se trate, na lição sempre inolvidável de Ascarelli, de um contrato plurilateral. e não 
simplesmente bilateral —, parece-nos que a inserção de um dispositivo específico no Livro II apresentaria, a nosso ver, pelo menos duas vantagens ponderáveis.

Em primeiro lugar, ela daria uma "demonstração de coerência interna e externa" do Código, como oportunamente destacado por Waldírio Bulgarelli.

Em segundo lugar - e sobretudo - , pelo fato de que essa função social deve ser cumprida. não apenas pelas sociedades em geral, mas igualmente pelo empresário individual. A norma do art. 421 alcança, tecnicamente falando, a figura das sociedades em geral - quer as empresárias, quer as não-empresárias —, mas não abarca a atividade do empresário individual que a exerce, como é curial, independentemente da existência de um contrato de sociedade... ${ }^{69}$

Cabe abrir novo parêntese, a propósito, para dizer que o NCC, infelizmente, não terá sido rigorosamente simétrico na inclusão de um Livro II, intitulado Direito de Empresa, no qual existem apenas, esparsamente, algumas normas subre Direito da empresa.

Veja-se, por exemplo, a crítica feita pelo Eminente professor Fábio Konder Comparato, em exposição igualmente feita na Câmara dos Deputados, após expressar o seu desencanto diante da malograda tentativa do Código no sentido de tentar harmonizar a disciplina civilística com o regime jurídico do Direito empresarial. Pondo em realce a inadequação dessa parte, asseverou o ilustre jurista:

O Livro consagrado à atividade negocial $\square$ disciplina dos empresários e das sociedades $\square$ surge como um corpo estranho no Código, sem ligação interna e necessária com as demais partes da obra. Se o empresário é definido como o que exerce, profissionalmente, atividade econômica organizada para a produção ou circulação de hens ou de serviços, causa espécie que a Parte Geral, estendendo-se longamente sobre o negócio jurídico, segundo a tradição da pandectistica alemã, não contenha uma única disposição sobre a atividade jurídica, que com aquele se não confunde. Tanto em matéria de capacidade quanto de validade ou de eficácia, atividade se distingue de ato ou de negócio jurídico. Ora, o conceito de atividade empresarial, em substituição ao vetusto ato de comércio, constitui a pedra angular do moderno Direito Comercial.

"Se isto sucede com o empresário em geral, algo de semelhante ocorre com as sociedades. O Projeto as retira do Livro das Obrigações e do título dos contratos. Como ligá-las, então, com as demais categorias do Dircito Privado? Ato jurídico coletivo

69 Foi o que defendemos em nosso artigo intitulado DE LUCCA, Newion. A atividade empresarial no àmbito do Projeto de Código Civil. In: SIMÃO FILHO, Adalberto; DE LUCCA, Newlın. Nir iro Empresarial Contemporâneo. 2. ed. São Paulo: Ed. Juarez de Oliveira, 2004. p. 31 e ss. 
ou contrato plurilateral? O Projeto ignora totalmente esta última categoria, consagrada pelo Código italiano, e que é sem dúvida fundamental para a solução de várias questões particulares do Direito societário, como o desfazimento parcial do vínculo - por resolução, rescisão ou resilição - e a sua invalidade parcial" ${ }^{70}$

Veja-se, por derradeiro - e em remate do presente capítulo - , o art. 422 do NCC:

Os contraentes são ohrigados a guardar, assim na conclusão do contrato, como em sua execușão, os principios de probidade e de boa-fé.

Pode-se dizer — não-obstante a crítica que se fará, logo mais adiante, da redação deste dispositivo - que ele, no tocante à boa-fé, terá sido bem mais avançado do que o famoso Código de Defesa do Consumidor brasileiro. Diz-nos a respeito a autorizada voz do Eminente ministro Ruy Rosado de Aguiar Jr.:" "O Código Civil de 2002 tem disposições mais amplas e completas. Como já constavam do Projeto de 1975. que se transformou no Código de 2002, verificamos que o legislador civil de 1975, nesse ponto, foi mais avançado do que o do Código de Defesa do Consumidor e melhor, até, do que o foi o de outros paises em que se dispôs sobre a cláusula da boa-fé"

Relativamente ao art. 422, essa mesma I Jornada aprovou os seguintes Enunciados, de n. 24, 25, 26 e 27, do seguinte teor:

24 - Em virtude do principio da boa-fé, positivado no art. 422 do novo Código Civil, a violaçáa dos deveres anexos constitui espécie de inadimplemento, independentemente de culpa.

25 - O art. 422 do Código Civil não inviabiliza a aplicação, pelo julgador, do principio da boa-fé nas fases pré e pós contratual.

26 - A cláusula geral contida no art. 422 do novo Código Civil impõe ao juiz interpretar e, quando necessário, suprir e corrigir o contrato segundo a boa-fé objetiva, entendida como a exigência de comportamento leal dos contratantes."

27 - Na interpretação da cláusula geral da boa-fé, deve-se levar em conta o sistema do Código Civil e as conexões sistemáticas com outros estatutos normativos e fatores metajuridicos.

70 Cf. COMPARATO, Fábiu Konder. Direitu Empresarial. São Paulo: Saraiva, 1990.

$"$ Cf. AGUIAR JÚNIOR, Ruy Rosado de. U Novo Código Civil e o Código de Defesa do Consumidur (Pontos de Convergência). Revista da Escola da Magistratura do Estado do Rio de Janeiro, n. esp., 2004. Anais dos Seminários EMLRJ Debate o Novo Código Civil, parte Il, p. 238, jul. 2002 a abr. 2003. 
Mais uma vez se verifica, pelo teor de tais Enunciados, a preocupação dos operadores do Direito de explicitar o efetivo conteúdo das disposições no novo Código. Não teria sentido, com efeito, que a boa-fé devesse estar presente apenas nas fases de conclusão e de execução do contrato, como está expresso nesse artigo 422. Como esclarece o Enunciado supra, de n. 27, deve-se levar em conta, na interpretação da cláusula geral da boa-fé. o sistema do Código Civil, não fazendo nenhum sentido de que essa mesma boa-fé fosse dispensável nas fases pré e pós contratual, como oportunamente esclarece o Enunciado supra, de n. 25.

Nem todas as questões delicadas, talvez, terão sido resolvidas por esses dispositivos do novo Código Civil que acabamos de analisar. perfunctoriamente, mas a utilização dos princípios neles consagrados poderá levar a tal resultado. Diz-nos, a propósito, o E. prof. Gustavo Tepedino, da Faculdade de Direito da Universidade Estadual do Rio de Janeiro: ${ }^{72}$

Fundamentalmente, portanto, a função social do contrato e a boa-fé, antes restritas às relações de consumo, tiveram seu campo de atuação ampliado, abrangendo todas as relações contratuais. Muito embora algumas questões controvertidas não tenham sido diretamente resolvidas pelo novo Código, os intérpretes poderão fazê-lo, bastando recorrer a tais princípios.

3 Normas de interpretação no Código de Defesa do Consumidor (Lei n. 8.078, de 11 de setembro de 1990)

Antes de iniciarmos a análise das normas de interpretação no Código de Defesa do Consumidor - seja no que se refere à interpretação dos contratos, seja no que respeita às relações de consumo, genericamente consideradas $^{73}$ parecem pertinentes

72 Cl. AGUIAR JÚNIOR, Ruy Rosado de. O Novo ('ódigo Civil e o Código de Defesa do Consumidor (Pontos de Convergência). Revista da Escola da Magistratura do Estado do Rio de Janeiro, n. csp., 2004. Anais dos Seminários EMERJ Debate o Novo Código Civil. parte II, p. 238. jul. 2002 a abr. 2003. p. 185.

${ }^{73}$ A distinção é justificada pela maior abrangência da uxpressão relação di consumo em cotejo com a que possui a expressão contratos de consumo. Nelson Nery Júnior já houvera formulado, desde a primeira edição da obra (NFRY JÚNIOR, Nelson. Código Brasileiro de Defesa do Consumidor comentado pelos autores do antcprojeto. 4. ed. Rio de Janeiro: Forense Universitária, 1995. p. 283), o seguinte insinamento a respeito:"Objcto de regulamentação pelo Código de Defesa do Consumidor é a relação de consumo. assim entendida a relação juridica existente entre fornecedor e consumidor tendo como objeto a aquisição de produtos ou utilização de serviços pelo consumidor", esclarecendo oportunamente, em nota de rodapé, o caráter plurissêmico da expressão consumidor. Aduz, ainda, que "o CDC não fala de "contrato de consumo", "ato de consumo", "negócio juridico de consumo", mas de relaçāo de consumo. termo que tem sentido mais amplo do que aquelas expressões. São elementos da relação de consumo, segundo o CDC: a) como sujeitos, o fornecedor e o consumidor; b) como objeto, os produtos e serviços; c) como finalidade. caracterizando-se como elemento teleológico das relaçōes de consumo. serem elas celebradas para que o consumidor adquira produto ou se utilize de serviço 'como destinatário final' (art. $2^{\circ}$. caput, última parte. 
algumas breves considerações sobre o significado da proteção ao consumidor, no Brasil, erigida a preceito constitucional, desde 1988, conforme se pode ver cm duas normas de grande relevo.

Em primeiro lugar — de importância fundamental por tratar-se de cláusula pétrea ${ }^{4}$ - destaca-sc o inciso XXXII, do art. $5^{\circ}$ da Constituição Federal, verbis:

O Estado promoverá. na forma da lei, a defesa do consumidor.

Encartado entre os dircitos e garantias fundamentais do cidadão brasileiro, a sua importância, absolutamente decisiva a respeito da matéria, foi destacada incisivamente pelo professor Fábio Konder Comparato, ${ }^{\text {‘ }}$ in verbis:

Por outro lado, a defesa do consumidor é, indubitavelmente, um tipo de principio-programa, tendo por objeto uma ampla política pública (public policy). A expressão designa um programa de ação de interesse público. Como todo programa de ação, a politica pública desenvolve uma atividade, i. e., uma série organizada de ações, para a consecução de uma finalidade, imposta na lei ou na Constituição. A imposição constitucional ou legal de politicas é feita, portanto, por meio das chamadas 'normasobjetivo" cujo conteúdo, como já se disse, é um 'Zweckprogramm' ou 'Finalprogramm'(Cf. KochRüssmann, Juristische Begründungslehre. Munique, 1982.pp. 85 e ss.). Quer isto dizer que os Poderes Públicos detêm um certo grau de liberdade para montar os meios adequados à consecução desse objetivo obrigatório. É claro que a implementação desses meios exige a edição de normas -- tanto leis. quanto regulamentos de Administração Pública: mas essa atividade normativa não exaure. em absuluto. o conteńdo da policy, ou programa de ação

\section{CDC)."}

74 Os constirucionalistas brasileiros de expressão (José Afonso da Silva, Paulo Bonavides, Alexandre de Moraes e outros) relerem-se às cláusulas pétreas quando cuidam do tema das "Jimitações ao poder de reforma constitucional", classificando-as em: limitações temporais. quando, por exemplo, a própria Constituição estabelece em seu texto a proibição de ser reformada antes de um certo lapso de tempo da sua vigência (Exemplo: art. 174, da Constituição brasileira do tempo do Império): limitaçōes circunstanciais, quando a Constituição proibe emendas em determinadas circunstâncias, como no caso da vigência do estado de sítio. da defesa e intervenção federal (art. $60, \S 1^{\circ}, \mathrm{CF} / 88$ ) e, finalmente, as limitaçöes materiais (explicitas e implicitas) que são as materias excluidas do poder de reforma, denominadas pela doutrina, justamente, de cláusulas pétreas, constantes do art. $60, \$ 4^{\circ}, \mathrm{CF} / 88$. A elas se refere o prof. Alexandre de Moraes. verbı: "Tais matérias formam o núcleo intangivel da Constituição Federal. denominado tradicionalmente por "cláusulas pétreas". (MORAES, Alexandre de. Direito Constitucional. 12. cd. São Paulo: Ed. Atlas, 2002. p. 544-5). Cf., em idèntico sentido: "As limitaçòes materiais também são chamadas cláusulas pétreas. E aquelas previstas no an. 60 , $\$ 4^{\circ}$, da CF são as clausulas pétreas explicitas" (CHIMENTI. Ricardo Cunha et al. Curso de Direilo Constitucional. São Paulo: Saraiva. 2004).

75 COMPARATO, Fábio Konder. A Proteção ao Consumidor na Constituição Brasileira de 1988. Revista de Direito Mercantil. Industrial, Econômico e Financeiro, São Paulo. v. 29, n. 80, p. 66-75, out./dez. 1990. 
pública. É preciso não esquecer que esta só se rualiza mediante a organização de recursos materiais e humanos, ambos previstos e dimensionados no orçamentoprograma. $^{76}$

Nossa Constituição Federal, no entanto, afirma que temos, entre os fundamentos da República Federativa do Brasil, a dignidade da pessoa humana (art. 1. inciso III).

Temos a triste sensação, no entanto, de que a noção ética do que seja dignidade humana ainda não terá sido suficientemente desenvolvida entre os brasileiros. " Alguns autores de nomeada procuraram mostrar a importância do conccito, mas não me parece que tenhamos chegado, contudo, a uma conscientização de seu verdadeiro conteúdo c alcance.

O E. professor da Faculdade de Direito da Universidade de São Paulo hoje ministro da mais alta Corte de Justiça do Brasil — Eros Roberto Grau, por exumplo. refere-se especificamente ao tema, asseverando:

A dignidade da pessoa humana i adotada pelo texto constirucional concomitantemente como fundamento da República Federativa do Brasil (art. 1, III) e como fim da ordem econômica (mundo do ser) (art. 170, caput a ordem econômica ... tem por fim assegurar a todos existência digna').

E prossegue trazendo à lembrança o art. $1^{\circ}$ da Lei Fundamental da Repúhlica Federal alemã: "A dignidade do homem é inviolável. Respeitá-la e protegê-la é obrigação de todo o poder público" 78

José Afonso da Silva, ${ }^{79}$ em lição que também merece ser transcrita, observa que a dignidade prevista na Constituição Federal "obriga a uma densificação valorativa que tenha em conta o seu amplo sentido normativo-constitucional e não uma qualquer idéia aprioristica do homem, não podendo se reduzir o sentido de dignidade

76 Para um estudo da importância das politicas públicas e da possibilidade de um controle jurisdicional sobre elas, veja-se. do mesmo autor, o importantissimo COMPARATO. Fábio Konder. Ensaio sobre o juizo de constitucionalidade de politicas públicas. Revista de Informação Legislativa. Brasilia, v. 35, n. 138, p. 3948, abr./jun. 1998.

77 No que se refere à solidariedade humana, o seu sentido ético foi bem explicitado por (MONTESQUIEU, Charles-Louis de Secondat. Mes pensées, Oeuvres Complites. Paris: Ed. Gallimard, 1949. v. 1, p. 981): "Se eu soubesse de alguma coisa que fosse útil a mim, porém danosa à minha lámília; eu a rejeitaria de meu espirito. Se eu soubesse de alguma coisa útil à minha familia, porém não útil à minha pátria, procuraria esquecê-la. Se cu soubesse de alguma cotsa útil à minha pátria. mas danosa à Europa, ou então útil à Europa, mas danosa ao gênero humano, consideraria isso como sendo um crime"

78 No original alemão: "Die Würde des Mensch'" ist umantastbar. Sie zu achten und zu schürzen ist Verpflichtung aller staatichen Gewalt"

79 SILVA. Iosé Afonso da. Curso de Direito Constituciunal Positivo. 6. ed. 2. tir. Sào Paulo: Revista dos Tribunais. p. 93 
humana à defesa dos direitos pessoais tradicionais, esquecendo-se nos casos de direitos sociais, ou invocá-la para construir 'teoria do núcleo da personalidade' individual, ignorando-a quando se trata de direitos econômicos, sociais e culturais"

A norma de interpretação (considerada tal expressão em seu sentido estrito) constante no Código de Defesa do Consumidor é a que está no art. 47 , segundo a qual:

As cláusulas contratuais serão interpretadas de maneira mais favorável ao consumidor.

O Eminente professor Nelson Nery Jr. elogiou bastante este dispositivo, asseverando, textualmente, que: $:^{80}$

Como medida de notável avanço, a norma determina que a interpretação do contrato se faça de modo mais favorável ao consumidor. Não apenas das cláusulas obscuras ou ambiguas, como sugerido pelo art. 423 do Projeto de Código Civil n634-B, de 1975, que, aliás, limita essa prerrogativa ao aderente, nos contratos de adesão.

A Eminente prof . Cláudia Lima Marques, igualmente, sempre doutrinou no mesmo sentido, verbis: ${ }^{81}$

O novo Código Civil de 2002 prevê. em seu art. 423, o recurso à interpretação mais favorável ao aderente (interpretação contra proferentem), mas só em contratos de adesão e em cláusulas ambiguas ou contraditórias. $\mathrm{O}$ art. 47 do $\mathrm{CDC}$ representa, porém, uma evolução em relação a essa norma e à do art. 85 do CCB (e art. 112 do novo CCbr./2002), pois beneficiará a todos os consumidores, em todos os contratos, em todas as normas, mesmo as claras e não contraditórias, sendo que agora a vontade interna, a intenção não declarada. nem sempre prevalecerá. Em outras palavras. é da interpretação ativa do magistrado a favor do consumidor que virá a 'clareza' da cláusula e que será estabelecido se a cláusula, assim interpretada a favor do consumidor, é ou não contraditória com outras cláusulas do contrato.

Em nota de rodapé relativa à "clareza" da cláusula, cita a professora Cláudia Marques dois interessantes arestos do Superior Tribunal de Justiça (RESP 196302/SP. julgado em 18/02/99. de relatoria do E. min. Ruy Rosado de Aguiar e RESP

80 Cf. NERY JÚNIOR, Nelson. Código Brasileiro de Defesa do Consumidor Comentado pelos Aulor's do Anteprojeto. 4. ed. Rio de Janeiro: Forense Universitária, 1995.

81 Cf. MARQl ES, Cláudia Lima. Contratos no Código de Defesa do C'onsumidor. São Paulo: Revista dos Tribunais, 2002. p. 744-745. 
255065/RS, julgado em 05/04/01, de relatoria do E. min. Carlos Alberto Menezes Direito) cujas ementas possuem o seguinte teor, respectivamente:

Seguro de vida em grupo - Acidente - MicrotraumaAudição - Os microtraumas que o operário sofre quando exposto a ruído excessivo inclui-se no conceito de acidente, para o fim de cobertura securitária estabelecida em contrato de seguro em grupo estipulado pela sua empregadora. Precedentes...

"Seguro saúde - Cobertura - Cirrose provocada por vírus 'C' - Exclusão Precedentes. 1. Adquirida a doença muito tempo após a assinatura do contrato, desconhecida do autor, que, em outras oportunidades, obteve tratamento com reembolso, diante de situação semelhante, não há fundamento para a recusa da cobertura, ainda mais sendo de possível contaminação em decorrência de tratamento hospitalar, ocorrendo a internação diante de manifestação aguda, inesperada. 2. Recurso especial conhecido e provido" 82

Influenciado pelo brocardo "in claris cessat interpretatio", chegamos a nos manifestar, anteriormente, no sentido de que "só nas hipóteses de dubiedade ou contradição é que o princípio exegético se aplica. Se o contrato é claro, não há o que possa ser interpretado. Se houver cláusula abusiva contra o consumidor, a disposição contratual será afetada pelos arts. 51, 52 ou 53, conforme o caso, e não pelo art. 47 ${ }^{183}$

Já tivemos, no entanto, a oportunidade de reconhecer, publicamente, em algumas palestras realizadas, aquele nosso equívoco ${ }^{84}$ do passado. É o momento de fazêlo agora, novamente, e por escrito...

Em primeiro lugar, há que se repelir a origem romana da expressão "in claris cessat interpretatio" O jurista Carlos Maximiliano é absolutamente categórico a respeito: ${ }^{85}$

82 A profa Cláudia reforça essa sua idéia, na 4. edição de sua citada obra, a partir da adoção do principio da boa-lé objetiva. lambém pelo novo Código Civil brasileiro, conforme se pode ver a p. $742,1.1$ Interprelação pró-consumidor. Visão geral.

83 Cf. Direito do Consumidor - Aspeclos Práticos - Pergunlus e Respostas, 2. ed. Revista e ampliada. Edipro-Fdições Profissionais Lida., São Paulo, 2000, p. 77.

84 Os professores e magistrados Pablo Stolze Gagliano e Rodolfo Pamplona Filho. já anteriormente citados (Novo Curso de Direito Civil, vol. I, p. 67), afirmam, com razão incgável: "Como podemos verificar, o ditado "in claris cessat interprctatio" tem origem especifica no campo do Direito das sucessões. notadamente no que diz respeito às disposições de última vontade. Entretanto. na atividade jurídica, é muito comum valer-se dessa máxima para evitar uma interpretação mais aprofundada de algum dispositivo normativo." E concluem peremptoriamente: "Trata-se de equivoco manifesto, pois até mesmo para verificar se a hipótese fática submetida à apreciação é equivalente a outras já conhecidas é preciso interpretar" (grifos nossos)

" Cf. Hermenêufica e Aplicação do Direito, cit., p. 33-34. 
O brocardo - In claris cessat interpretatio, embora expresso $\mathrm{im}$ latim, não tem origem romana. Ulpiano ensinou 0 contrário: Quamvis sit manifestissimun edichum proctoris. attamen non est negligenda interpretatio ejus 'umbora claríssimo o edito do pretor, contudo não se deve descurar da interpretação respectiva

A este conceito os tradicionalistas opõem o de Paulo: Cum in verhis nulla ambiguitas est, non debet admitti voluntaris quoestio - 'Quando nas palavras não existe ambigüidade, não se deve admitir pesquisa acerca da vontade ou intenção'

O mal de argumentar somente com adágios redunda nisto: tomam-nos a esmo, isolados do repositório em que regiam muitas vezes casos particulares, e, descuidadamente. generalizam disposição especial. Quem abra o Digesto, logo observa que a máxima de Paulo só se refere a testamentos, revela um respeito, talvez exagerado. pela última vontade: evita que lhe modifiquem a essência, a pretexto di descobrir o verdadeiro sentido da fórmula verbal. Ao contrário. a parêmia de Ulpiano refere-se à exegese do que teve força de lei, ao Direito subsidiário, aos editos pretórios.

No campo legislativo, embora perfeita a norma, cumpre descer a fundo, à idéia. Prevalece ali o ensinamento de Celso: Scire leges non hoc est, verba earurm tenere, sed vim ac potestatem - 'saber as leis não é conhecer-lhes as palavras, porém a sua força e poder'. isto é, o sentido e o alcance respectivos.

A exegese, em Roma, não se limitava aos textos obscuros, nem aos lacunosos: c foi graças a essa largueza de vista dos jurisconsultos do Lácio que o Digesto atravessou os séculos e regeu institutos cuja existência Papiniano jamais pudera prever.

Como se infere, pois, desse trecho transcrito, apenas no que se referia às disposições de última vontade, no âmbito do Direito sucessório, fazia sentido a argumentação de Paulo: ela visava salvaguardar incólume, fundamentalmente. a vontade do testador. Para tanto, preciso era que não se lhe conspurcasse a essência, a pretexto de interpretar-se o significado da fórmula verbal... Exagerado ou não, como disse Carlos Maximiliano, foi o respeito à ultima vontade que orientou o pensamento de Paulo. Mas. tanto o ensinamento de Ulpiano quanto o de Celso tinham espectro mais largo. aplicando-se às interpretações legislativas e pretorianas em geral. ${ }^{8 / 6}$

Em segundo lugar. parece-nos agora irrecusável que não há como se chegar à conclusão de que uma determinada norma seja clara sem um mínimo de atividade própria da interpretação, concebida esta. como vimos em Betti. como um processo epistemológico de entender.

86 Para uma ampla investigação a respeito do brocardo "in claris cessat interpretatio" (de origem medieval e não romana), veja-se a obra de Alipio Silveira. hremenêtuica no Direito brasileiro, cit., vol. II, Revista dos Iribunais. São Paulo, dezembro de 1968, pp. 27 e ss. 
Vejam-se, a propósito, as seguintes considerações do jurista português, José de Oliveira Ascensão. ${ }^{87}$

Há uma tendência para confundir 'interpretação' e 'interpretação complexa' e supor que se a fonte é clara não ocorre fazer interpretação. Há mesmo um brocardo que traduz esta orientação: in claris non fit interpretatio. Perante um texto categórico da lei, por exemplo, o intérprete limitar-se-ia a tomar conhecimento.

"Esta posição é contraditória nos seus próprios termos. Até para concluir que a disposição legal é evidente foi necessário um trabalho de interpretação, embora quase instantâneo, e é com base nele que se afirma que o texto não suscita problemas particulares. Se toda a fonte consiste num dado que se destina a transmitir um sentido ou conteúdo intelectual, a que chamaremos o seu espírito, tem sempre de haver uma tarefa intelectual, por mais simples que seja, como extrair da matéria o espírito que a matéria encerra.

Passemos, agora, a outro ponto. Outras normas há, no Código de Defesa do Consumidor, que devem ser tidas por normas de interpretação em sentido amplo, conforme a distinção que adutamos neste trabalho. Referimo-nos, especialmente, em primeiro lugar, à norma constante do inciso III do art. $4^{\circ}$ segundo a qual um dos princípios da Política Nacional das Relações de Consumo é a "harmonização dos interesses dos participantes das relações de consumo e compatibilização da proteção do consumidor com a necessidade de desenvolvimento econômico e tecnológico, de modo a viabilizar os princípios nos quais se funda a ordem econômica (art. 170 da Constituição Federal), sempre com base na boa-fé e equilibrio nas relações entre consumidores e fornecedores"

Temos aqui aquela espécie de norma à qual a doutrina mais moderna designa de norma-objetivo. O já tantas vezes citado professor e ministro Eros Roberto Grau, ${ }^{88}$ em comunicação apresentada no "Seminário Internacional de Direito do Consumidor" realizado na cidade de São Paulo. no período de 24 a 27 de setembro de 1990, assim se manifestara a respeito:

Esta norma do art. 4.", realinente, não cabe nem no modelo de norma de condura, nem no modelo de norma de organização. Porque. na verdade, ela é uma normaobjetivo. Ela define fim a ser alcançado. Essas normas que definem fim $\square$ e que eu acho que nào são programáticas,

37 Cf. O Direito - Introdução e Teoria Geral - Uma perspectivu Luso-Brasileira, $2^{a}$ ed. Bras., Renovar, Rio de Janeiro, 2001, p. 403.

88 Contribuição para a interpretạ̧ão e a crítica da ordem económica na Constituição de 1988, Tese, São Paulo. 1990, p. 216. 
são normas de eficácia total, completa, absoluta, inquestionável, indiscutivel começam a surgir modernamente.

Posteriormente, em memorável conferência pronunciada em Canela, no Estado do Rio Grande do Sul, no dia 12 de março de 1992, durante o IV Congresso Internacional de Direito do Consumidor, intitulada Interpretação do Código de Defesa do Consumidor, esse mesmo professor voltou ao tema, com maior vigor ainda, sustentando ser esse artigo o mais importante do CDC, exatamente por encerrar uma verdadeira norma-objetivo, isto é. aquela que indica ao intérprete o sentido teleológico da norma editada. ${ }^{89}$

Essa opinião - com a qual, em numerosas palestras, temos nos manifestado irrestritamente de acordo - foi compartilhada pela maior parte da doutrina, devendo ser relembrada, entre outras, a posição do E. prof. Fábio Konder Comparato, anteriormente transcrita, comentando a existência de normas-objetivo, igualmente no plano constitucional.

Ninguém mais sustenta, nos dias que correm. que o Direito seja composto apenas por normas de conduta e normas de organização. Sempre ouvimos, nos bancos acadêmicos de antanho, com efeito, que o Direito se compunha dessas duas modalidades de normas, sendo o Código Penal o clássico exemplo da norma de conduta enquanto a Lei de Sociedade por Ações seria o tradicional exemplo de norma de organização.

O grande jurista Norberto Bobbio cuidou de pôr a nu a evidente insuficiência dessa distinção, demonstrando que as normas de organização, pclo simples fato de serem normas, não poderiam deixar de ser, igualmente, normas de conduta.

São suas palavras, textualmente: "Né appare immediatamente chiaro il criterio in base al quale questo tipo di norma viene distinto da un altro tipo di norma, chiamato 'norma di condotta' se non altro perchè anche le norme di organizzazione, per il solo fatto di essere norme. sono norme di condotta", concluindo, de forma peremptória, que: "Pertanto, se la distinzione ha un senso, essa non può essere fondata sul fatto che vi siano norme che regolano la condotta e altre che regolano qualcosa di diverso dalla condotta. ma evidentemente, deve poggiare su qualche altra base che la infelice terminologia nasconde" 90

Nunca nos convencemos, com efeito, da prestabilidade de tal distinção, quer de sua possível funcionalidade específica, quer de seu acerto científico. Se é verdade, como consta do exemplo, que a Lei de Sociedade por Ações se constitui,

89. Cf. Interpretando o código de defesa do consumidor: algumas nolas. Revista de Direito do Consumidor $n^{\circ}$ 5, pp. 183 e ss.

90 Dalla Struttura alla Funzione, Nuovi studi di teoria del diritto. Edizioni di Comunita, Milão, 1977, p. 125. 
essencialmente, numa norma de organização, como deixar de reconhecer que ela não seja, também, uma norma de conduta, especialmente quando - sem embargo dos numerosos exemplos que poderiam ser formecidos — cuida dis dever de diligência do administrador? ${ }^{91}$

Assim, sem embargo de todas as outras considerações que poderiam ser aduzidas a respeito dessa velha dicotomia, o certo é que a função que, modernamente, desempenham as normas-objetivo, tal como o citado art. $4^{\circ}$ do $\mathrm{CDC}$ brasileiro, assume decisiva importância no contexto da civilização contemporânea.

O que se pode dizer, em sintese, é que todas essas normas do CDC destinadas à proteção contratual dos consumidores estão calcadas, quer nas próprias normas de natureza principiológica, constantes do início do Cćdigo. quer nas diretrizes constitucionais já mencionadas no sentido da proteção ao consumiclor.

Ficou definitivamente para trás aquela hipocrisia consubstanciada na igualdade das partes diante do contrato, assim como na afirmação peremptória de que este deve necessariamente ser cumprido, independentemente de considerações de ordem pública.

Não se concebe mais, na sociedade contemporânea. que o contrato possa se apresentar com o aparato do definitivo. Mesmo nos já distintes tempos de Goethe, este grande gênio haveria de exprimir tal idéia em versos inolvicláveis: ${ }^{92}$

Quand le monde s'agite de tous les orag,es, crois-tu qu'un simple mot d'écrit soit une obligation assez puissante?

Na lição de São Tomás de Aquino ${ }^{93}$ — o grande tıólogo da Igreja Católica - entre as condições indispensáveis para que um ato seja moralmente bom, é evidente que a subordinação a um fim legítimo prepondere sobre todos os outros. Um ato moral perfeitamente bom é o que plenamente satisfaz as exigências da razão. no fím comum de cada uma das partes e que, não satisfeita de querer o bem. realiza-o.

Mas quando uma coisa é considerada boa? Para São Tomás uma coisa é assim quando ela pode ser considerada perfeita. Perfeito, por seu turno, é aquilo a que nada falta. É o que é por sua forma que. por sua vez, determina a sua essência. Na filosofia tomista. em suma, para que algo seja perfeito e bom. deverá reunir,

\footnotetext{
"1 Diz, o artigo 153 da Lei n." 6.404, de 15 de dezembro de 1976: "O administrador da companhia deve empregar. no exercicio de suas funções, o cuidado e diligência que todo homem ativo e probo costuma empregar na udministração dos seus próprios negócios."

92 Fausto, tradução francesa de Gérard de Nerval, Éditions Gallimard, Paris, 1)51, p. 993.

93 Cf. Gilson Étienne, Le Thomisme, Paris, 1948, pp. 363/364.
} 
simultaneamente, a forma que lhe convém, seus antecedentes autênticos e seus conseqüentes naturais... ${ }^{94}$

Trazida a discussão para o âmbito dos contratos, o que poderia ser considerado boin na sociedade contemporânea?... A ideologia dominante é que determina o que é bom ou não o é... E., nesse sentido, lapidar a frase do jurista argentino Mossct Iturraspe: $:^{95}$

"El contrato suffe los avatares de la ideologia imperante".

São Paulo, outubro de 2006.

\section{Referências}

AGUIAR JÚNIOR, Ruy Rosado de. O Novo Código Civil e o Código de Defesa do Consumidor (Pontos de Convergência). Revista da Escola da Magistratura do Estado do Rio de Janeiro, número especial 2004; Anais dos Seminários EMERJ Debate o Novo Código Civil, parte II, julho/2002 a abril/2003.

ALMEIDA, Carlos Ferreira de. Os Direitos dos Consumidores. Cuimbra: Livraria Almedina. 1982.

. Introdução ao Direito Comparado. 2. ed. Coimbra: Almedina, 1998.

ANCEL, Marc. Litilidade e Métodos do Direito Comparado. Tradução Sérgio José Porto. Porto Alegre: Sérgio Antonio Fabris Editor, 1980.

ARISTÓTELES. Politica. Edição bilingüe (grego e português). Tradução e notas António Campelo Amaral i Carlos de Carvalho Gomes. Lisboa: Editora Vega, 1998.

ARRLDA ALVIM, José Manuel. A sintonia da redação do art. 112 do Código Civil com os princípins contemporâneos do negócio jurídico bilateral e do contrato. Revista do Advogado, São Paulo, ano. XXIV. n. 77, julho. 2004.

ASCARELli. Tullio. O contrato plurilateral. in Problemas das Sociedudes Anônimus e Direito Comparado. 2. ed. São Paulo: Saraiva, 1969.

A idéia de Código no Direito Privado e a tarefa da interpretação. In: PROBLEMAS das Sociedades Anônimas e Direito Comparado. 2. ed. São Paulo: Saraiva, 1969.

is Cr. A. D. Sertillanges, La philosophie de S. Thomas. Paris. 1940, p. 53.

95 Cf. Interpretación Economica de los Contratos. Rubinzal-Culzoni Editores. Santa Fé. Argentina, julio de 1994 
ASCENSÃO. José de Oliveira. O Direito, introdução e teoria geral: uma perspectiva lusobrasileira. 2. ed. Rio de Janeiro: Renovar, 2001.

AZEVEDO, Álvaro Villaça. Teoria geral dos cuntratos tipicos e atípicos: curso de Direito Civil. São Paulo: Ed. Atlas, 2002.

AZEVEDO, Antonio Junqueira de. A boa-fé na formação dos contratos. Revista de Direito do Consumidor, São Paulo, n. 3, p. 78-87, set./dez. 1992.

Insuficiências, deficiências e desatualização do Projeto de Código Civil na questão da boa-fé objetiva nus contratos. RTDC Revista Trimestral de Direito Civil. Rio de Janeiro, v. 1, n. I, p. 3-12, jan./mar. 2000.

. O Direito Pós-Moderno c a Codificação. Revista de Direito do Consumidor, São Paulo, n. 33, p. 123-129. jan./mar. 2000.

Negócio Juridico: existência, validade e eficácia. 193p. Tese (Livre-docência) Faculdade de Direito, L'niversidade de São Paulo.

BETTI, Emilio. Teoria Generale della Interpretazione. Milão: Giuffrè, 1955. Interpretazione della legge e degli atti giuridici. Milão: Giuffrè, 1971.

BEVILÁqua. Clóvis. Código Civil dos Estados Unidos do Brasil Comentado. II. ed. Rio de Janeiro: Francisco Alves, 1956. ․ I.

Teoria Geral do Mireito ('ivil.5. ed. Rio de Janeiro: Francisco Alves, 1929.

BITTAR, Carlos Alberto. (iurso de Direito Civil. Rio de Janeiro: Ed. Forense U'niversitária, Iy9y. BOBBIO, Norberto. Sul positivismo ginridico. LII Rivista di Filosofia 14. 1961.

Dalla Strutura Alla Funzione: Nuovi Studi di Teoria del Diritto. 2. ed. Milão: Ed. di Comunità, 1984.

De senectute e altri scritti autobiografici. Turim: Einaudi. 1996.

BONAVIDES, Paulo. Curso de Direito Constitucional. 6. ed. São Paulo: Malhciros,.

CARRIÓ, Genaro R. Notas sobre Derecho y lenguagu. 4." ed. Buenos Aires: Abeledo-Perrot, 1990.

CHIMENTI, Ricardo Cunha et al. Cursu de Direito Constitucional. São Paulo: Saraiva. 2004.

COMPARATO, Fábio Konder. A Ruforma da Empresa. Revista de Direito Mercuntil, n. 50. abr.jun. 1983.

. Direito Empresarial. São Paulo: Saraiva, 1990. 
. Novos Ensaios e Pareceres de Direito Empresarial. Rio de Janeiro: Forense, 1978.

COMPARATO. Fábio Konder. A proteção ao consumidor na Constituição Brasileira de 1988. Revistu de Direito Mercantil, Industrial, Economico e Financeiro, São Paulo, v. 29. n. 80. p. 6675 , out./dez. 1990.

. Ensaio sobre o juízo de constitucionalidade de políticas públicas. Revista de Informação Legislativa, Brasília, v. 35, n. 138, p. 39-48, abr./jun. 1998.

SILVA, José Afonso da. Curso de Direito Constitucional Positivo. 7. ed. São Paulo: Revista dos Tribunais, 1991.

DE LUCCA, Newton. Direito do Consumidor: Teoria Geral da Relação Juridica de Consumo. São Paulo: Editora Quartier Latin, 2003.

A atividade empresarial no âmbito do Projeto de Código Civil. In: SIMÃO FILHO, Adalberto; DF LUCCA, Newton (Coord.). Direito Empresarial Contemporâneo. 2. ed. São Paulo: Juarez de Oliveira, 2004.

Direito do Consumidor - Aspectos Práticos - Perguntas e Respostas. 2. ed. rev. e ampl. São Paulo: Edipro-Edições Profissionais Ltda., 2000.

DINIZ, Maria Helena. Lei de Introdução uo Código Civil Interpretada. 7. ed. São Paulo: Saraiva. 2001 .

ÉTIENNE, Gilson. Le Thomisme. Paris: J. Vrin, 1947.

FLUME, Werner: El negocio juridico: parte general del derecho civil. Tradução espanhola. Madrid: Ed. Fundación Cultural del Notariado, 1998. tomo II. cap. VIII.

Gagliano, Pablo Stolze; PAMPLONA Filho, Rodolfo. Novo Curso de Direito (ivil: parte geral. São Paulo: Saraiva, 2002.v. 1.

GOMES, Orlando. A Agonia do Direito Civil, conferência proferida no Encontro Nacional de Mestres de Direito Civil, realizado em homenagem a ele. Ed. Ciência Jurídica.

Introdução ao Direito Civil. 14. ed. Rio de Janeiro: Forense, 1998.

Transformações Gerais do Direito das Obrigações. 2. ed. Aum. São Paulo: Revista dos Tribunais, 1980.

A Caminho dos Microssistemas: novos temas de Direito Civil. Rio de Janeiro: Forense, 1983.

Contratos. Rio de Janeiro: Editora Forense, 1984. 
Obrigações. 4. ed. Rio de Janeiro: Forense, 1976.

GRAU, Eros Roberto. Contribuição para a interpretação e a crítica da ordem econômica na Constituiçẫo de 1988. 1990. 336p. Tese (Titular) -.. Faculdade de Direito. Universidade de São Paulo, São Paulo.

GOETHE, Johann Wolfgang. Fausto. Tradução francesa de Gérard de Nerval. Paris: Éditions Gallimard, 1951.

IRTI, Natalino. La società civile, elementi per un analisi di Diritto Privatto. Milão: Giuffrè, 1992. _. L'età della decodificacazione. Milão: Giuffrè, 1979.

KEMPIS, Tomás de. Imitação de Cristo. São Paulo: Ed. Martin Claret. 2002.

LOHMANN LUCA DE TENA, Guillermo. La Interpretación de la ley y de los actos jurídicos en el derecho peruano, in Interpretación de los contratos. Revista de derecho Comparado, n. 3, Buenos Aires, fevereiro. 2001.

LORENZETTI, Ricardo Luis. Tratado de los Contratos: parte general. Santa Fé, Argentina: Rubinzal-Culzoni Iditores, 1999. . Fundamentos do Direito Privado. São Paulo: Revista dos Tribunais, 1998.

MARQUES, Cláudia Lima. Confiança no comércio eletrônico e a proteção do consumidor negócios juridicos de consumo no comércio eletrônico. São Paulo: Revista dos Tribunais, 2004.

Contrutos no Código de Defesa do Consumidor: 4. ed. São Paulo: Revista dos Tribunais, 2002.

MAXIMILIANO, Carlos. Hermenêutica e Aplicação do Direito. 19. ed. Rio de Janeiro: Editora Forense, 2004.

MENDONÇA, Manuel Inácio Carvalho de. Doutrina e Prática das Obrigações ou tratado geral dos direitos de crédito. 4. ed. Rio de Janeiro: Forense. 1956. v. 2.

MIRANDA. Francisco ('avalcanti Pontes de. Tratado de Direito Privado: parte especial. 3. ed. São Paulo: Revista dos Tribunais, 1984. t. 38.

MONTESQUIEU, Charles-Louis de Secondat, Barão de la Brède e de. O espirito das leis. 2. ed. rev. Tradução Fernando Henrique Cardoso e Leôncio Martins Rodrigues. Brasília: Editora Universidade de Brasília, 1995. . Mes Pensées, Oeuvres Complètes. Paris: Ed. Gallimard, 1949. v. 1.

MORAES, Alexandre de. Direito Constitucional. 12. ed. São Paulo: I:d. Atlas. 2002. 
MOSSET ITURRASPE, Jorge. Interpretacion Economica de los Contralos. Santa Fé, Argentina: Rubinzal-Culzoni Editores, 1994.

NFRY JÚNIUR, Nelson. Código Brasileiro de Defésa do Consumider comentudo pelos autores do anteprojeto. 4. ed. Rio de Janeiro: Forense Univursitária, 1995.

Os Principios Gerais do Código Brasileiro de Defesa do Consumidor. Revista de Direito do Consumidor. n. 3, p. 44-77. set./dez. 1992.

REALE, Miguel. O Projeto do Novo Código Civil. 2. ed. ref. e atual. São Paulo: Saraiva. 1999.

Discurso proferido na cerimônia especial dedicada à sanção da Lei que instituiu o novo Código Civil no Brasil.

RECASÉNS SICHES, Luis. Tratado General de Filosofia del Derecho. 5. ed. México: Editorial Porrua, S.A., 1975.

Nueva Filosofia de la Interpretación del Derccho. México: Fondo de Cultura Económica. 1956.

Experiencia juridica, naturaleza de la cosa y Lógica "razonable" México: Fondo de Cultura Económica, Universidad Nacional Autónoma de México, 1971.

SERTILlAngES, A. D. La philosophie de S. Thomas. Paris: 1940.

SILVEIRA, Alipio. Hermenêutica no Direito brasileiro. São Paulo: Revista dos Tribunais, 1968. v. I e ll.

SOUZA, Miriam de Almeida. A Politica Legislativa do Consumidor no Direito Comparado. Salvador: Nova Alvorada Edições, 1996.

TEPEDINO, Gustavo José Mendes. Problemas de Direito Civil Constitucional. Introdução: O Código Civil, os chamados microssistemas e a Constituição: premissas para uma reforma legislativa. In: Problemas de Direito Civil. Rio de Janeiro/São Paulo: Ed. Renovar, 2000.

Os Novos Contratos no Novo Cúdigo Civil. Revista da EMERJ, Rio de Janeiro, n. esp. p. 179-93. fev./jun. 2002.

As Relações de Consumo c a Nova Teoria Contratual. Revista de Estudos Juridicos da PUC-PR. v. IV, n. I, ago. 1997.

Temas de Direito Civil. Rio de Janeiro/São Paulo: Ed. Renovar. 1999.

THEODORO JÚNIOR, Humberto. Comentários ao Novo Código Civil. Obra coletiva coordenada pelo Ministro Sálvio de Figueiredo Teixeira. 1. ed. Rio de Janeiro: Ed. Forense, 2003. v. IIl, tomo I 
TRINDADE, Washington Luiz da. O Superdireito nas Relações de Trabalho. Salvador: Ed. e Distr. de Livros Salvador Ltda., 1982.

VARELA, João de Mattos Antunes. Das obrigações em geral. 7. ed. Coimbra: Editora Almedina, 1991.v. I.

O movimento da descodificação do Direito Civil. In: ESTUDOS juridicos em homenagem ao Professor Caio Mário da Silva Pereiru. Rio de Janeiro: Editora Forense, 1984.

VENOSA, Sílvio de Salvo. Teoria geral dos contratos. 2. ed. São Paulo: Atlas, 1996. 